\title{
THE PARADOX OF AUXILIARY RIGHTS: THE PRIVILEGE AGAINST SELF-INCRIMINATION AND THE RIGHT TO KEEP AND BEAR ARMS
}

\author{
MichaEL STEVEN GREEN†
}

\begin{abstract}
According to Locke's theory of the social contract, which was widely accepted by the Founders, political authority is limited by those natural moral rights that individuals reserve against the government. In this Article, I argue that Locke's theory generates paradoxical conclusions concerning the government's authority over civil disobedients, that is, people who resist the government because they believe it is violating reserved moral rights. If the government lacks the authority to compel the civil disobedient to abide by its laws, the result is anarchism: The limits on governmental authority are whatever each individual says they are. If the government has this authority, the result is authoritarianism: The limits on governmental authority are whatever the government says they are. Both conclusions are unacceptable.
\end{abstract}

Because of the Lockean paradox, auxiliary constitutional rights, whose purpose is to protect civil disobedience, are likewise paradoxical. I argue that the Fifth Amendment privilege against selfincrimination and the Second Amendment right to keep and bear arms are examples of auxiliary rights, and I use the Lockean paradox to explain the intractable nature of the debates over whether these two rights provide anything of moral value. To their critics, these rights are anarchistic. All they do is give individuals the power to frustrate

Copyright (C) 2002 by Michael Steven Green.

$\dagger$ Assistant Professor, George Mason University School of Law. Ph.D. (Philosophy), Yale University, 1990; J.D., Yale Law School, 1996. I would like to thank David Bernstein, Kiersten Boyce, Nelson Lund, Dan Polsby, Richard Posner, and an audience at the University of London's Institute for Advanced Legal Studies for helpful comments. This Article was written with support from George Mason University School of Law and its Center for Law and Economics. Thanks also go to King's College School of Law at the University of London for providing me with a home during my sabbatical leave from George Mason. 
the government's legitimate attempts to protect citizens against mutually-imposed risks of violence. To their supporters, these rights are a bulwark against authoritarianism. To deny citizens the power to resist the government is to accept that the only views about the limits of political authority that matter are the government's. These disagreements cannot be resolved, because both sides are right. Supporters of these rights are anarchistic and their critics are authoritarian. As long as we continue to accept the Founders' Lockean view that governmental authority is limited by reserved moral rights, we will never be able to reject or accept these two constitutional rights.

The Lockean paradox also explains the difficulties that courts and academics have experienced delineating the scope of these rights in a conceptually satisfying manner. Here too I argue that these problems cannot be overcome. The limits that are placed on these rights will always be arbitrary and ad hoc.

\section{TABLE OF CONTENTS}

Abstract 113

Introduction

I. The Paradox of Auxiliary Rights.................................................... 119

A. The Lockean Paradox ................................................................. 119

B. A Taxonomy of Constitutional Rights ..................................... 122

C. Blackstone on Auxiliary Rights .............................................. 128

II. The Paradox and the Privilege against Self-Incrimination ........ 133

A. Standard-Right Justifications ................................................... 134

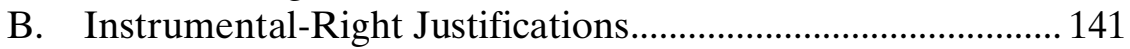

C. Auxiliary-Right Justifications................................................. 145

D. The Privilege's Incoherent Scope ........................................... 149

III. The Paradox and The Right to Bear Arms ................................. 156

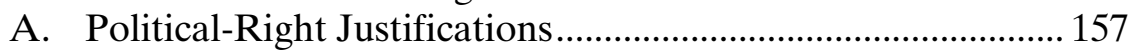

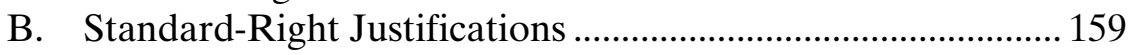

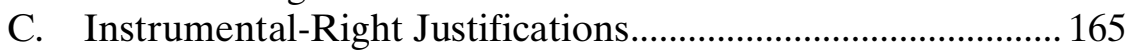

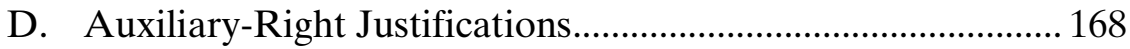

E. The Second Amendment's Incoherent Scope ........................ 173

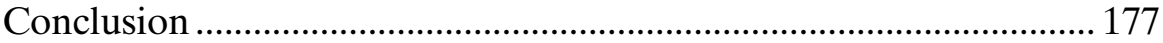

\section{INTRODUCTION}

The Bill of Rights is a legacy of John Locke's theory of the social contract. Like Locke, the Founders believed that governmental 
authority depends upon the consent of the governed. ${ }^{1}$ For this reason, it cannot be unlimited. Individuals submitting to the authority of the state can, and sometimes must, ${ }^{2}$ retain certain natural moral rights. The Bill of Rights protects these reserved rights. ${ }^{3}$

Social contract theory stands at the heart of judicial and academic interpretation of the Bill of Rights. For example, the Fourth Amendment's legal scope has generally been read in the light of the moral right of privacy, ${ }^{4}$ which, it is argued, has been reserved against the government even at the cost of reduced efficiency in the administration of the criminal law. ${ }^{5}$ Other provisions in the Bill of Rights are also commonly interpreted in the light of reserved moral rights. ${ }^{6}$

1. See LeOnard W. LeVy, Original Intent And the Framers' Constitution 139 (1988) ("Over a period of a century and a half [before the adoption of the Constitution], America became accustomed to the idea that government existed by the consent of the governed."); Greg Sergienko, Social Contract Neutrality and the Religion Clauses of the Federal Constitution, 57 OHIO ST. L.J. 1263, 1268-72 (1996) ("[T]he Framers and the public ... conceived governments as resulting from an agreement among people to provide a means for enforcing existing rights."). See also BERNARD BAILYN, THE IDEOLOGICAL ORIGINS OF THE AMERICAN REVOLUTION 182-87 (1967) (discussing the Founders' belief that government should be founded on a permanent constitution approved by the people); GORDON S. WOOD, THE RADICALISM OF THE AMERICAN REVOLUTION 164-66 (1992) (comparing the English "paternalistic" form of government with the colonial contractual form of government).

2. Rights must be reserved when they are inalienable. For Locke's surprisingly narrow view of inalienable rights, see generally A. John Simmons, Inalienable Rights and Locke's Treatises, 12 PHIL. \& PUB. AFF. 175 (1983).

3. United States v. Verdugo-Urquidez, 494 U.S. 259, 287-88 (1990) (Brennan, J., dissenting) ("[T]he Framers of the Bill of Rights did not purport to 'create' rights. Rather, they designed the Bill of Rights to prohibit our Government from infringing rights and liberties presumed to be pre-existing."). Some Federalists used Lockean social contract theory to argue that a Bill of Rights is dangerous. Since these rights were retained by individuals, the government had no authority to take them away, and thus no authority to grant them to individuals by law. Thomas B. McAffee, The Bill of Rights, Social Contract Theory, and the Rights "Retained" by the People, 16 S. ILL. U. L.J. 267, 267-69 (1992).

4. See Warden v. Hayden, 387 U.S. 294, 304 (1967) ("[T]he principal object of the Fourth Amendment is the protection of privacy."); see also Wolf v. Colorado, 338 U.S. 25, 27-28 (1949) (stating that the Fourth Amendment protects "human rights"); Boyd v. United States, 116 U.S. 616, 630 (1886) (noting that the Fourth Amendment protects "indefeasible" rights).

5. See Akhil Reed Amar, Fourth Amendment First Principles, 107 HARV. L. REV. 757, 785 (1994) (arguing that the Fourth Amendment must be interpreted in light of "interests of personhood, property, and privacy"); Ken Gormley, One Hundred Years of Privacy, 1992 WIS. L. REV. 1335, 1357-74 (describing privacy-right interpretations of the Fourth Amendment); William J. Stuntz, The Distribution of Fourth Amendment Privacy, 67 GeO. WASH. L. REV. 1265, 1265 (1999) (describing "widespread agreement" in literature on the subject that the Fourth Amendment should protect the right of privacy).

6. For a classic expression of the view that the Bill of Rights protects reserved moral rights, see Ronald DwOrkin, FreEdom's LAw: THE Moral READING OF THE AMERICAN CONSTITUTION 2 (1996) (advocating "moral reading" of the Constitution that interprets Constitutional provisions as incarnations of abstract moral principles); RONALD DWORKIN, TAKING 
But for decades the privilege against self-incrimination has been at the center of academic controversy, because it appears incompatible with this theory. ${ }^{7}$ The scope of the privilege, critics argue, fails to correspond to the scope of any reserved moral right. More recently, a similar academic controversy has developed concerning the moral purpose of the Second Amendment right to keep and bear arms. ${ }^{8}$

Some defenders of these two rights have developed an alternative account of their moral purpose that appears in keeping with social contract theory. ${ }^{9}$ The privilege and the Second Amendment are auxiliary: they give individuals the power to defend their reserved rights when other forms of legal protection fail. ${ }^{10}$

RIGHTS SERIOUSLY 190-91 (1977) [hereinafter DWORKIN, RIGHTS] ("If citizens have a moral right of free speech, then governments would do wrong to repeal the First Amendment that guarantees it, even if they were persuaded that the majority would be better off if speech were curtailed."). Reserved moral rights are not used to justify every constitutional right. For example, such an approach is not appropriate for rights that ensure the separation of powers or the preservation of the federal structure. Id. at 191; R. Kent Greenawalt, Silence as a Moral and Constitutional Right, 23 WM. \& MARY L. REV. 15, 52-53 (1981). For examples of interpretations of specific provisions in the Bill of Rights in the light of reserved moral rights, see Abe Fortas, The Fifth Amendment: Nemo Tenetur Prodere Seipsum, 25 CLEV. B. Ass'N J. 91, 97-98 (1954) (reading the Fifth Amendment privilege against self-incrimination in the light of reserved natural rights); Sergienko, supra note 1, at 1268-72 (reading the Establishment and Free Exercise Clauses of the First Amendment in light of social contract theory and reserved natural rights); Suzanna Sherry, The Founders' Unwritten Constitution, 54 U. CHI. L. REV. 1127, 1161-67 (1987) (reading the Ninth Amendment in light of reserved natural rights).

7. See Akhil Reed Amar \& Renee B. Lettow, Fifth Amendment First Principles: The SelfIncrimination Clause, 93 MICH. L. REV. 857, 889-98 (1995) (rejecting rights-based accounts of the privilege as unable to explain its scope); David Dolinko, Is There a Rationale for the Privilege Against Self-Incrimination?, 33 UCLA L. REV. 1063, 1090-1147 (1986) (same); cf. Daniel J. Seidmann \& Alex Stein, The Right to Silence Helps the Innocent: A Game-Theoretic Analysis of the Fifth Amendment Privilege, 114 HARV. L. REV. 430, 435-37 (2000) (rejecting the view that the privilege protects only the rights of the guilty).

8. See, e.g., Michael A. Bellesiles, Suicide Pact: New Readings of the Second Amendment, 16 CONST. COMment. 247, 256 (1999) (rejecting individual-rights justifications of the Second Amendment); William Van Alstyne, The Second Amendment and the Personal Right to Bear Arms, 43 DUKE L.J. 1236, 1239-41 (1994) (showing sympathy for the National Rifle Association's individual-rights stance on the Second Amendment); David C. Williams, Civic Republicanism and the Citizen Militia: The Terrifying Second Amendment, 101 YALE L.J. 551, 586-94 (1991) [hereinafter Williams, Civic Republicanism] (rejecting views that the Second Amendment protects personal rights); David C. Williams, The Militia Movement and Second Amendment Revolution: Conjuring with the People, 81 CoRNELl L. REV. 879, 911-15 (1996) [hereinafter Williams, Militia Movement] (same); David Yassky, The Second Amendment: Structure, History, and Constitutional Change, 99 MICH. L. REV. 588, 615-21 (2000) (rejecting individualrights justifications of the Second Amendment).

9. See infra note 35 .

10. That these two rights have their source in the Lockean social contract theory helps explain why they are taken more seriously in American legal and political traditions than they are on the European continent. See MirJan R. DAmašKa, The FACES OF Justice and STATE 
This Article is an exploration of auxiliary rights. My conclusion is surprising. I argue that auxiliary rights are paradoxical. By this I do not mean that they are contradictory and should be rejected. Instead, I mean that they can never be consistently accepted or rejected-so long as one adheres to the Founders' Lockean ideal of governmental authority limited by natural rights. As a result, courts will never be able to determine their scope in a coherent fashion. The limits courts place on these rights will always appear arbitrary and conceptually unmotivated.

The paradox of auxiliary rights is tied to a more fundamental paradox concerning the government's authority to forbid civil disobedience, that is, its authority to prohibit citizens' resistance to the state when they believe that its laws violate their reserved rights. On the one hand, if the government lacks this authority, its authority as a whole seems to evaporate. For individuals have the power to escape its authority, even when their reserved rights have not been violated, simply by believing that these rights have been violated. Lockeanism lapses into anarchism: the limits on the government's authority over an individual are simply whatever the individual says they are. ${ }^{11}$

On the other hand, if the government has the authority to forbid civil disobedience, then all limits on its authority seem to evaporate. For the government may do whatever it pleases to individuals, even when its actions violate their reserved rights, as long as it believes that

AUTHORITY 8-15, 71-180 (1986) (discussing the differences between the American and European legal traditions in relation to the privilege and the adversarial system); B. Bruce-Briggs, The Great American Gun War, 45 PUB. INT. 37, 61 (1976) (discussing the differences between American and European legal traditions in relation to the right to bear arms). American traditions are more strongly influenced by consent theories of the state than their continental counterparts, which tend to view citizens as having natural duties to join civil society. See DAMAšKA, supra, passim (describing the differences between the Anglo-American and continental political traditions).

11. It is because of the threat of anarchism that those who engage in civil disobedience are generally considered legally obligated to accept punishment for their actions. Steven M. Bauer \& Peter J. Eckerstrom, Note, The State Made Me Do It: The Applicability of the Necessity Defense to Civil Disobedience, 39 STAN. L. REV. 1173, 1190 (1987); see also CARL COHEN, CIVIL DisOBEDIENCE: CONSCIENCE, TACTICS, AND THE LAW 76-91 (1971) (discussing the objectives met by punishing civil disobedience); Sidney Hook, Social Protest and Civil Disobedience, in Civil DisobediEnCE AND Violence 59 (Jeffrie J. Murphy ed., 1971) (arguing that those who resort to civil disobedience are obligated to accept punishments and legal sanctions because attempts to evade those punishments "erode the moral foundation of civil disobedience"). Even those who argue that some forms of civil disobedience should be legally protected do not claim that the civil disobedient always has a right to this form of protection. See, e.g., Hugo Bedau, On Civil Disobedience, 58 J. PHIL. 653, 663 (1961) (acknowledging that under certain circumstances, a government justifiably may force someone to act against his conscience). 
these rights have not been violated. Lockeanism lapses into authoritarianism: the limits on governmental authority are simply whatever the government says they are.

Just as civil disobedience is paradoxical within a Lockean framework, so are auxiliary rights, which legally protect civil disobedience. The debate concerning these rights cannot be resolved within the Lockean framework, because each side can justifiably accuse the other of violating a core Lockean principle. Because these rights give individuals the means to resist the state whenever they feel it is appropriate, even when their resistance violates the state's legitimate authority, critics of auxiliary rights can argue that they are "anarchistic" 12 and contrary to the "duty of citizenship."13 Auxiliary rights incoherently reintroduce the state of nature into civil society. However, if the state may refuse to provide citizens with auxiliary rights, it must have the authority to forbid legitimate defense of reserved rights. For this reason, supporters of auxiliary rights can argue that their critics are "totalitarian." ${ }^{14}$ Reserved moral rights mean nothing if the state may legitimately prohibit citizens from protecting these rights. Without auxiliary rights, the state's authority is unlimited.

This debate is at an impasse because both sides are right. The supporters of auxiliary rights are anarchists, and their critics are totalitarians. The paradox ensures that no coherent middle ground between anarchism and totalitarianism can be staked out. The intractable nature of the debate over auxiliary rights is the reflection of an irresolvable conflict within Lockean political theory itself, and is a testimony to this theory's importance within the American political and legal tradition.

This Article is divided into three parts. In Part I, I discuss in greater detail the Lockean paradox of civil disobedience and its ability to generate persuasive arguments both for and against auxiliary rights. In Part II, I outline how the paradox of auxiliary rights has generated irresolvable disagreement concerning the justifiability of

12. Carl T. Bogus, The Hidden History of the Second Amendment, 31 U.C. DAVIS L. REV. 309, 320 (1998).

13. Amar \& Lettow, supra note 7, at 892; see also DoLINKO, supra note 7, at 1144 (contending that autonomy-right justifications of the privilege are incompatible with "the whole institution of the criminal law," which is a testimony "to our reluctance to give free play to each individual's notions of what is right and wrong").

14. David Harmer, Securing a Free State: Why the Second Amendment Matters, 1998 BYU L. REV. 55, 55-56; see also ERWIN N. GRISWOLD, THE FIFTH AMENDMENT TODAY 70 (1955) ("The totalitarian mind accepts all the means which promise the achievement of its ends."). 
the privilege against self-incrimination, and how it has frustrated all attempts to delineate the scope of the privilege in a coherent fashion. In Part III, I do the same concerning the right to bear arms.

\section{THE PARADOX OF AuXILIARY RightS}

A paradox arises when a set of plausible premises collectively generates, through acceptable reasoning, implausible or absurd conclusions. ${ }^{15}$ Lockean social contract theory is paradoxical because, although prima facie plausible, the theory generates implausible conclusions concerning the authority of the government when the government disagrees with individuals about whether it has violated their reserved rights.

I begin this Part by describing the Lockean paradox of civil disobedience in greater detail. I then identify four types of constitutional right (political, standard, instrumental, and auxiliary) on the basis of the moral role that each plays within a Lockean theory of the state, and argue that, because of the Lockean paradox, there are compelling arguments both for and against auxiliary rights. I end Part I with a discussion of how William Blackstone's theory of auxiliary rights, which Second Amendment advocates often cite, is a response to the Lockean paradox.

\section{A. The Lockean Paradox}

The heart of Locke's theory of the social contract is that citizens have contracted with one another to give up to the political community certain rights that they had in the state of nature, most importantly their rights to adjudicate and punish violations of natural law. ${ }^{16}$ Because people tend to interpret their own rights and the rights of their kin too broadly, ${ }^{17}$ private enforcement of natural law leads to feuding, which puts everyone in a worse position than they would be if they were subject to a single adjudicator. After entering into the social contract, rather than being permitted to act on one's own judg-

\footnotetext{
15. R.M. SAINSBURY, PARADOXES 1 (1988).

16. John Locke, The Second Treatise of Government, in Political Writings of JOHN LOCKE $§ \$ 94-99$ (David Wooton ed., 1993) (1681).

17. Id. $\S \S 13,125$.
} 
ment about whether natural rights have been violated, one is bound by the decisions of the majority of the political community. ${ }^{18}$

But it is also essential to Locke's theory that citizens retain certain natural rights against the community. ${ }^{19}$ If these rights are violated, individuals return to the state of nature and may exercise their natural entitlement to protect themselves. ${ }^{20}$ The Lockean paradox of civil disobedience arises when one considers disagreements between individuals and their political community about whether a reserved right has been violated. Only two conclusions appear possible: either the community has the authority to determine whether these reserved rights have been violated (and so the authority to forbid citizens' attempts to defend their rights), or it does not.

If it does not have this authority, then political authority as a whole is undermined. To escape one's obligations to the community, all a citizen has to do is believe that the community has violated one of her reserved rights. For example, if the political community taxes individuals progressively, the wealthy may escape the obligation to pay most of their taxes if they believe that they reserved the right to pay only a poll tax-even if, in fact, they reserved no such right. Political authority would exist only if the individual believes that it does. But political authority was supposed to obligate individuals to abide by the decisions of the political community whether or not they believe its decisions are correct.

One might argue that the community may still forbid resistance to its laws despite its lack of authority over the civil disobedient, because, like any other player within the state of nature, it is free to act on the basis of its views about natural law. Since it believes that it has not violated reserved rights, it may act on this perception. But such an argument conflicts with a core Lockean principle. For Locke, the community can exercise a monopoly on coercive power only if it has authority, not simply because it thinks its views are right and happens to have the power to enforce its will. ${ }^{21}$ If the ability to coerce dissenters to abide by its moral judgment were enough to justify the political

18. Id. $\S \S 95,99 ;$ A. JOHN SIMMONS, ON THE EDGE OF ANARCHY: LOCKE, CONSENT, AND THE LiMits OF SOCIETY 69-71 (1993); D.A. LLOYD THOMAS, LOCKE ON GOVERNMENT 27 (1995).

19. LOCKE, supra note 16, §§ 131, 135, 149, 168, 172.

20. Id. $\S \S 168,208$.

21. See THOMAS, supra note 18 , at 49 ("[Locke] wants to show that a government which has been instituted in the appropriate way, and which honestly tries to enforce the law of nature has authority over its citizens."). 
community's monopoly on force, there would be no need for the social contract in the first place. ${ }^{22}$ Accordingly, if the political community lacks authority over the civil disobedient, it has no right to coerce compliance with its laws.

On the other hand, if the community does have the authority to determine whether reserved rights are violated, then all limits on its authority evaporate. For the community may violate reserved rights whenever the majority within it believes that they have not been violated. It does not matter that citizens entering civil society in fact reserved a right against discrimination according to religion. The political community may nevertheless prohibit Catholicism and justifiably punish Catholics for resisting, provided that the majority comes to the conclusion that no right against religious discrimination was reserved or that the prohibition of Catholicism does not violate this right. Political authority exists whenever the community believes it does. But reserved rights, if violated, were supposed to free individuals from any duty to the community-no matter how the community viewed the matter.

The conclusion one wants to reach is that political authority ends not when the individual thinks it does and not when the community thinks it does, but precisely when reserved moral rights have been violated. As a moral principle, this is unobjectionable. But since there can be disagreements about its application, consent theories of the state must answer the question whether the political community has the authority to decide these disagreements. The paradox of civil disobedience is that whatever position one takes on this matter, some element of Lockean political theory is violated.

The paradox helps explain Locke's muddled approach to civil disobedience. On the one hand, he sometimes insists that those who consent to join the political community are bound to accept its decisions, no matter what. ${ }^{23}$ To give the individual the right to "plead exception" to the social contract would render it voidable at will. ${ }^{24}$ As a

22. Id. I came to a different conclusion in Michael S. Green, The Privilege's Last Stand: The Privilege Against Self-Incrimination and the Right to Rebel Against the State, 65 BROOK. L. REV. 627, 698-99 (1999). There I argued that social contract theory has the obligation to explain only the moral possibility of governmental authority, not answer the question of who has the authority to decide if authority exists. In cases of disagreement about political authority, the government may simply act on the basis of its perception that it has authority, without claiming authority to decide this disagreement.

23. LOCKE, supra note $16, \S \S 87,88$.

24. Id. $\S 994,243$. 
result, he argues that the political community alone has the right to resist tyranny. ${ }^{25}$ Locke's considered view, however, appears to be that an individual does have the right to defend herself against the community if it violates her reserved rights: "And where the body of the people, or any single man, is deprived of their right, or is under the exercise of a power without right, and have no appeal on earth, there they have a liberty to appeal to heaven, whenever they judge the cause of sufficient moment." ${ }^{26}$ But if the individual may plead exception to the social contract, has it not been rendered voidable at will, just as Locke himself feared? Locke provides no answer.

\section{B. A Taxonomy of Constitutional Rights}

So far I have described the paradox of civil disobedience as arising when an individual and the political community disagree about whether reserved rights are violated. ${ }^{27}$ In fact, their disagreement would not be direct, because the political community does not exercise its authority over individuals through concrete political decisions, but only by entrusting its powers to a government. ${ }^{28}$ If the political community has entrusted its powers to a government and this government does not violate reserved rights, its decisions are binding upon citizens. The real paradox of civil disobedience arises, therefore, when an individual and a government that maintains the political community's trust disagree about whether the government has violated the individual's reserved rights.

Because the government has only that authority delegated to it by the political community, the community may demand as a condi-

25. Id. $\S \S 149,240,243$; see also SIMMONS, supra note 18, at 172-74 ("The standard reading ... seems to be that Locke's right of resistance can be held only by the body of the people, its proper exercise to be determined only by the majority of the body politic."); THOMAS, supra note 18, at 70 ("Apparently Locke's meaning is that the deprivation of the rights of a particular person may be a sufficient occasion for the majority to withdraw its consent, but no one has a right to resist unless this single instance has persuaded the majority to withdraw its consent.").

26. LOCKE, supra note $16, \S 168$ (emphasis added). Indeed he is concerned to show that the general recognition of this right will not create serious disorder, since aggrieved individuals cannot overcome the coercive power of the political community as a whole. $I d$. $\S \S 208,230$. There would be no need to respond to this worry if individuals did not have the right of resistance to begin with. See SIMMONS, supra note 18, at 174-77 (arguing that Locke's writings support an individual right of resistance). Locke's appeal to the political community's power to compel compliance is, however, odd. Presumably he does not mean that it has the right to compel compliance, for this would be in violation of the Lockean principle that a monopoly on force is justified only given authority.

27. See supra Part I.A.

28. LOCKE, supra note 16, §§ 136, 149, 211-12, 221-22, 240. 
tion for this delegation a constitutional restriction on the government's freedom of action. If the community accepts Lockean political theory, this restriction is likely to be informed by Lockean principles, outlined above, concerning the source and limits of the government's and the community's authority. In this section I discuss four types of constitutional right that might be demanded by the community: political, standard, instrumental, and auxiliary. I argue that a Lockean political community would demand an auxiliary right in order to protect those forms of civil disobedience that are morally permissible according to Lockean political theory. But because civil disobedience has a paradoxical place within this theory, the auxiliary right will also be paradoxical.

I begin, however, with political rights, which exist to ensure that the delegation of authority from the political community to the government has in fact occurred. Although the act of trust that legitimates a government is majoritarian in nature, the government receiving this trust need not be democratic. ${ }^{29}$ The only moral right that an individual has to influence the decisions of the government is her right to participate in the creation of the trust that the political community as a whole gives to the government. ${ }^{30}$ Nevertheless, the majoritarian nature of this trust makes it appropriate for the political community to entrust its authority only to a government with a democratic political structure, because that can ensure that the community's trust is maintained. Furthermore, the community might give its trust only to a government that provides individuals with constitutional rights, such as the right to vote, that protect democratic participation in governmental decisions. These individual constitutional rights whose purpose it is to ensure that the government retains the political community's trust are political rights.

But it is also natural for the political community to demand, as a condition for the delegation of its authority, constitutional provisions that protect what the community believes are individuals' reserved rights. Because these reserved moral rights trump even the majoritarian interests of the political community, they are likely to be pro-

29. Id. §§ 132-33; RUTH W. GRANT, JOHN LOCKE’S LIBERALISM 117-19 (1987); THOMAS, supra note 18 , at $27-29$.

30. Since many of the legitimate governments that Locke describes are those in which the individual has no ability to influence the decisions of the government, he cannot believe that individuals have a right to such influence-except for the right to participate in the trust that the political community gives to a government and the right to withdraw that trust through a communitarian revolution. 
tected through countermajoritarian constitutional rights that have a scope similar to the scope of these reserved moral rights. I call these constitutional rights, which would include the Fourth Amendment and most other provisions in the Bill of Rights, standard rights.

In addition to standard rights, the political community might demand of the government certain countermajoritarian constitutional rights that protect reserved moral rights indirectly. These constitutional rights would not have a scope that is similar to the scope of any reserved moral right. Rather than protecting reserved moral rights directly, they would protect something that tends to protect reserved moral rights. An example of such an instrumental right is the right to a trial by jury. If one has a reserved natural right in criminal procedure, it is not the right to a jury of one's peers, but the right to a reasonable and impartial factfinder, which receives standard-right protection in the Constitution through the Due Process Clause. But because the government is not always in a position to know whether this reserved right has been violated, an imperfect instrument, the jury, might also be protected, because there is reason to believe that protecting the jury will indirectly protect the reserved right. ${ }^{31}$

The moral argument for instrumental rights is thoroughly empirical. Because the only reason for the institutional right is its tendency to protect reserved moral rights, there will be no reason for the institutional right if it fails to perform this function. If it turns out that juries are irredeemably irrational and biased, no moral argument for a right to a jury trial exists. ${ }^{32}$ Arguments for standard rights are not empirical in this sense. Because what they protect is the reserved moral right itself, they are justified by straightforward moral arguments that the reserved right exists.

Of course, there is a sense in which all constitutional rights are instrumental, for it will always be morally relevant whether a constitutional right, as an empirical matter, actually protects what it sets out to protect. It would undoubtedly be morally relevant if the Fourth Amendment failed for some reason to protect privacy. But instrumental rights have an extra element of instrumentalism that makes

31. See, e.g., Colleen P. Murphy, Integrating the Constitutional Authority of Civil and Criminal Juries, 61 GEO. WASH. L. REV. 723, 727-54 (1993) (interpreting the right to a jury trial as instrumental to the fundamental right to a rational and impartial factfinder).

32. No reason, that is, given the instrumental-right rationale presented immediately above. Other rationales for the right to a jury trial could be constructed. See, e.g., AKHIL REED AMAR, THE BILl OF RightS: CREATION AND RECONSTRUCTION 271-73 (1998) (interpreting the right to a jury trial in light of a prospective juror's right to participate in government). 
them vulnerable to empirical arguments to which standard rights are immune. The right to a jury trial is vulnerable not merely to arguments that it fails to provide citizens with jury trials, but also to arguments that jury trials fail to provide citizens with anything morally worthwhile.

In contrast, the argument for auxiliary rights rests upon the undeniable possibility that even a government with a constitution that contains standard and instrumental rights might nevertheless violate reserved moral rights. All standard and instrumental rights do is give legal force to the political community's views about the limits of governmental authority. Their existence is neither a necessary nor a sufficient condition for a government respecting reserved moral rights. A direct democracy with no standard or instrumental rights in its constitution can respect reserved rights, and a government with such constitutional restrictions can violate reserved rights, either because the restrictions are ignored or because they fail to track the moral rights that were actually reserved by individuals. In the end, all standard and instrumental rights, no matter how countermajoritarian they are legally, are the expression of the view of the majority of the political community. And there is no assurance that these views will be correct. For this reason, civil disobedience even against a government restricted by standard and instrumental rights can be morally legitimate.

Auxiliary rights are intended to address situations where standard and instrumental rights fail to protect reserved moral rights, and civil disobedience is morally permissible. But any attempt to identify and constitutionally protect only those particular citizens entitled to civil disobedience would simply create another communitarian vision of the extent of reserved rights-against which individuals might still justifiably engage in civil disobedience. Comprehensive protection of legitimate civil disobedience is possible only by giving individuals the power to resist according to their views about governmental authority. This is what an auxiliary right does. It gives to individuals those powers to resist the government to which they would be entitled if the government were violating their reserved rights.

But auxiliary rights are just as paradoxical as the civil disobedience they protect. On the one hand, they are necessary to avoid authoritarianism. Assume that the government argues that auxiliary rights are unnecessary because it is satisfied that its standard and instrumental rights are sufficient to protect reserved rights. By giving this argument, the government must be claiming the authority to decide disagreements concerning reserved rights. It is not enough that it 
is simply satisfied that reserved rights are protected and has the power to coerce individuals who disagree. It must have authority over these individuals. But if it has the authority to decide disagreements concerning reserved rights, its authority is unconstrained by these rights. The only constraints on its authority are its beliefs about reserved rights. And this is contrary to Lockean principles concerning the extent of political authority.

On the other hand, to give individuals auxiliary rights is to give them the power to frustrate the state's actions simply because they believe that their reserved rights are violated. Auxiliary rights allow citizens to frustrate the state even when it asserts legitimate authority. They are anarchistic. And this is also contrary to Lockean principles concerning the extent of political authority.

Indeed, because they allow each individual to act on the basis of her perceptions of natural rights, auxiliary rights reintroduce the state of nature into civil society. As a result, they can recreate the very problem that motivated the social contract in the first place. Permitting individuals to act on the basis of their perceptions of natural rights can, in the long run, make everyone's natural rights less secure. Although auxiliary rights exist to protect natural rights against violation by the government, their long-term effect can be an increase in the violation of natural rights.

Auxiliary rights are easily confused with both instrumental and standard rights. Consider the subtle but crucial differences between the following standard-, instrumental-, and auxiliary-right interpretations of the right to bear arms. ${ }^{33}$

Assume that in the state of nature individuals have a natural right to use arms to protect themselves against violations of their other rights. If bearing arms is a natural right, then it has moral value even if the aggregate effects of everyone exercising this right are negative. That there is a natural right to privacy means that privacy has value even if constant surveillance by the police would make individuals more secure in their persons and property. By the same token, if there is a natural right to use arms in self-defense, then this use of arms has value even if universal disarmament would reduce the chances that other rights would be violated. ${ }^{34}$

33. I discuss these arguments more fully in Part III, infra.

34. See infra Part III.B (arguing that a natural right to bear arms in self-defense follows from Lockean principles). 
If there is such a natural right to bear arms, and individuals reserved it upon entering civil society, then a government would have to respect this right if it is to retain political authority over individuals. A standard right to bear arms would help ensure that the government stayed within these bounds by establishing a constitutional entitlement with a scope comparable to the scope of this reserved right.

On the other hand, assume that this natural right to bear arms does not exist or would not be reserved upon entering civil society. Nevertheless, if the widespread use of arms for self-defense as an empirical matter made it more likely that people's other reserved rights would be respected by the government or third parties, this would be an argument for an instrumental right to bear arms. The right to bear arms would be justified, not because bearing arms has moral value in itself, but because the aggregate effect of allowing individuals to bear arms is the protection of reserved rights. Understood as instrumental, however, the right is vulnerable to empirical counterarguments. If it is discovered that widespread gun ownership makes reserved rights less secure, then the right to bear arms can be abolished without any moral loss. Since a foundational principle of Lockean political theory is that individuals' self-interest tends to distort their perceptions of their natural rights, an instrumental-right interpretation of the right to bear arms is in tension with Lockeanism. For an instrumental-right interpretation assumes, contrary to Locke's own views, that allowing individuals to enforce their perceptions concerning natural rights increases the likelihood that natural rights will be respected.

Finally, if the right to bear arms is auxiliary, it would exist to allow individuals to exercise their natural right to use arms to defend their other rights, not because they reserved this right upon entering civil society, but only because they will be freed from the restraints of civil society if the government violates their reserved rights. Unlike an instrumental right to bear arms, the fact that the aggregate effect of this use of arms for self-defense is an increase in the level of violations of natural rights is not a reason to reject this auxiliary right. Freed of any duty to the government, individuals return to the state of nature, and may once again do what they need to do to protect their rights, without concern for whether the aggregate effect of everyone exercising the same rights of self-defense is positive or negative. Therefore, like a standard right to bear arms, it would not be an argument against this auxiliary right that bearing arms, in the aggregate, does nothing to make us more secure in our persons and property. 
But there is a critical difference between an auxiliary and a standard right to bear arms. If the right to bear arms is standard, then every person bearing arms in self-defense is properly exercising his reserved right, just as every person asserting Fourth Amendment protections is properly exercising his right to privacy. But if the right to bear arms is auxiliary, only those engaging in legitimate civil disobedience, that is, those whose other reserved rights are being violated by the government, are legitimately exercising their natural right to bear arms. Those whose reserved rights are being respected by the government could have their arms taken away in the interest of mutual security. An auxiliary right to bear arms nevertheless applies to everyone because the government would be claiming absolute political authority if it attempted to discriminate between legitimate and illegitimate civil disobedience.

\section{Blackstone on Auxiliary Rights}

I have adopted the term "auxiliary right" because it is often used by Second Amendment advocates to describe the legal protection of the natural right to defend oneself against governmental violations of reserved rights. ${ }^{35}$ They in turn borrowed the term from William Blackstone, whose Commentaries on the Laws of England was influenced by Lockean social contract theory, ${ }^{36}$ and who was himself an important influence on the Founders and on the early development of American law. ${ }^{37}$ In his Commentaries, Blackstone described the right to bear arms as an auxiliary right, that is, a "barrier[] to protect and maintain inviolate ... primary rights.",38

35. Joyce Lee Malcolm, To Keep And Bear Arms: The Origins of AN ANGloAMERICAN Right 130 (1994); Robert J. Cottrol \& Raymond T. Diamond, The Second Amendment: Toward an Afro-Americanist Reconsideration, 80 GEO. L.J. 309, 322-23 (1991); Don B. Kates, Jr., The Second Amendment and the Ideology of Self-Protection, 9 Const. Comment. 87, 93 (1992); $f$. Nelson Lund, The Second Amendment, Political Liberty, and the Right to Self Preservation, 39 ALA. L. REV. 103, $120 \mathrm{n} .41$ (1987) (citing Blackstone as being in favor of the view that the right to bear arms is an absolute right).

36. See e.g., 1 WILliam BLACKSTONE, COMMENTARIES *120-23 ("So that laws, when prudently framed, are by no means subversive but rather introductive of liberty; for (as Mr. Locke has well observed) where there is no law, there is no freedom.").

37. See Donald S. Lutz, The Origins of American Constitutionalism 142-44 (1988) (demonstrating that Blackstone was the second most cited author during the Founders' time); Albert W. Alschuler, Rediscovering Blackstone, 145 U. PA. L. REV. 1, 5-19 (1996) (discussing Thomas Jefferson's reliance on Blackstone's Commentaries).

38. 1 BLACKSTONE, supra note 36 , at *136; see also id. at *139-41 (describing the auxiliary right to bear arms). 
But, contrary to prevailing interpretations of Blackstone among Second Amendment advocates, he did not think that the right to bear arms exists to allow individuals to resist a majoritarian government. The reason is that, unlike Locke, Blackstone did not believe that individuals have any reserved moral rights that could justify such resistance. ${ }^{39}$ Indeed, because Blackstone thought that the only moral right that members of civil society have is the right to participate in the collective trust that gives governments legitimacy, he concluded that no countermajoritarian legal rights should exist either. In the end, Blackstone's "auxiliary" rights are actually political rights, that is, legal rights whose function is to ensure that the trust that the political community gives to the government is maintained. The reason he comes to this surprising conclusion is the Lockean paradox.

Like Locke, Blackstone accepts the idea of the social contract, that is, the view that everyone gives up the "natural liberty" or "power of acting as one thinks fit" that one possesses in the state of nature "in consideration of receiving the advantages of mutual commerce." ${ }^{40}$ Entering civil society, he argues, obliges one "to conform to those laws, which the community has thought proper to establish." ${ }^{41}$ At first glance, it also appears that, like Locke, Blackstone believes that individuals have reserved rights against the political community. After all, he speaks of personal security, personal liberty and private property as "absolute" constitutional rights. ${ }^{42}$ But Blackstone rejects the idea that violations of an individual's life, liberty or property allow her to resist the political community. His reason is the Lockean paradox.

Blackstone interprets these three absolute constitutional rights in the light of disagreements between the political community and individuals about whether these rights have been violated. If the political community lacks the authority to judge whether it has trespassed against these rights, then civil society is undermined. To return to the state of nature, a citizen merely would have to believe that the community has violated one of these rights.

39. See infra notes 43-58 and accompanying text; see also Steven J. Heyman, Natural Rights and the Second Amendment, 76 CHI.-KENT L. REV. 237, 252-60 (2000) (observing that Blackstone believed that only the political community as a whole has the right to resist tyranny).

40. 1 BLACKSTONE, supra note 36, at *121; see also Heyman, supra note 39, at 255 (describing Blackstone's interpretation of the social contract).

41. 1 BLACKSTONE, supra note 36 , at $* 121$.

42. Id. at $* 136$. 
It is for this reason that Blackstone denies that individuals may defend these absolute rights against the political community. Civil disobedience is justifiable only when "the public voice proclaims such resistance necessary." ${ }^{43}$ Only the political community as a whole has the right of resistance, by withdrawing its trust from a tyrannical government. Giving "every individual the right of ... employing private force to resist even private oppression," Blackstone argues, is "productive of anarchy." ${ }^{44}$

By giving the community the authority to determine whether reserved rights are violated, Blackstone has nullified their role as a restriction on the community's political authority. The limits on its authority are simply whatever the community (and its legislature) says they are. To be sure, the community currently says that individuals have reserved rights to life, liberty and property. But individuals have these rights only because the community says so.

In short, the Lockean paradox compels Blackstone to give up either civil society or limited government. He chooses to give up limited government. He accepts that the political community, as expressed in the legislature, has an "absolute despotic power." ${ }^{45}$ The government has only those limits that it has imposed upon itself. It is the judge of its right to judge.

It is understandable, therefore, that Blackstone thinks of absolute constitutional rights not as countermajoritarian legal restraints on the legislature, but as the expression of the legislative will. It is natural for Americans to assume that by saying that absolute rights are part of "the constitution," ${ }^{46}$ Blackstone means that courts may strike down legislation that violates these rights. But he rejects judicial review as "subversive of all government," ${ }^{47}$ arguing that the legislature is "the sovereign power... [which] acknowledges no superior upon earth." " The political community must have entrusted its unlimited authority to some branch, and Blackstone argues that this branch was

\footnotetext{
43. Id. at $* 244$.

44. Id. at *244; see also id.:

For civil liberty, rightly understood, consists in protecting the rights of individuals by the united force of society: society cannot be maintained, and of course can exert no protection, without obedience to some sovereign power: and obedience is an empty name, if every individual has a right to decide how far he himself shall obey.

45. Id. at $* 156$.

46. Id.

47. $I d$. at $* 91$.

48. Id. at *90; see also id. at $* 157$.
} 
the legislature..$^{49}$ Blackstone's absolute constitutional rights are therefore best thought of as the will of the legislature, rather than a legal restraint upon its power. ${ }^{50}$

The same point applies to auxiliary rights. For Blackstone, auxiliary rights "serve principally as barriers to protect and maintain inviolate the three great and primary rights" ${ }^{151}$ by providing means for their enforcement. But since these three absolute rights are only the expression of the legislative will, auxiliary rights protect these absolute rights by sustaining and protecting legislative power.

Blackstone offers five examples of auxiliary rights. They are: (1) "[t]he constitution, powers and privileges of parliament"; (2) "the limitation of the king's prerogative, by bounds so certain and notorious, that it is impossible he should exceed them without the consent of the people"; (3) the right "of applying to the courts of justice for redress of injuries"; (4) "the right of petitioning the king, or either house of parliament, for the redress of grievances"; and (5) the right of the people "of having arms for their defense, suitable to their condition and degree, and such as are allowed by law." ${ }^{, 52}$ This final right is "a public allowance, under due restrictions, of the natural right of resistance and self-preservation, when the sanctions of society and laws are found insufficient to restrain the violence of oppression." ${ }^{, 53}$

According to Blackstone, the first auxiliary right protects absolute rights by encouraging a vigorous legislature, which makes it "improbable that laws should be enacted destructive of general liberty." Although this auxiliary right might give individual citizens a voice in the formation of the laws along majoritarian grounds, it does not give them the legal means to frustrate democratically enacted laws if these laws violate life, liberty or property. The second and the third auxiliary rights in turn merely ensure that parliamentary lawmaking power shall be enforced. The second right keeps the executive from "acting

49. Id. at *156 ("[Parliament] hath sovereign and uncontrolable authority in making, confirming, enlarging, restraining, abrogating, repealing, reviving, and expounding [all] laws ... this being the place where that absolute despotic power, which must in all governments reside somewhere, is entrusted by the constitution of these kingdoms.").

50. See Gordon S. Wood, The Creation of the American Republic 261 (1969) ("For Blackstone ... every act of Parliament was in a sense a part of the Constitution, and all law, customary and statutory, was thus constitutional.").

51. 1 BLACKSTONE, supra note 36 , at $* 136$.

52. Id. at $* 136-39$.

53. Id. at $* 139$.

54. Id. at $* 137$. 
either beyond or in contradiction to the laws, that are framed and established by [Parliament]," ${ }^{, 55}$ and the third right to judicial redress is the right to the "protection and benefit of the laws." that these are individual legal rights, they are merely rights that the majoritarian decisions of the legislature be respected. Likewise, the fourth auxiliary right, although providing yet another avenue for aggrieved citizens to have a voice in the formation of the laws, once again does not give them an avenue to frustrate the law's enforcement if life, liberty, or property are violated.

It might appear that Blackstone's fifth auxiliary right, which gives to the people "arms for their defence, suitable to their condition and degree," majority. But Blackstone insists that individuals have a right to bear arms "such as are allowed by law," legislature allows it. The right to bear arms is the expression of the community's will, not a restriction upon this will. It is the community's right to arm itself as a protection against a tyrannical minority, not an individual's right to arm herself as a protection against a tyrannical majority. To the extent that it puts arms in the hands of individuals, this entitlement is, like all of Blackstone's constitutional rights, a political right.

Of course, there is no reason to accept Blackstone's dismissal of judicial review. The political community is not required to place its trust in majoritarian legal institutions. It may give the judicial branch some or all of its political authority if it wishes, thereby giving that branch, and not the legislature, the authority to determine the extent of political power. But even if it does, the judicial branch just as much as the legislative may fail to protect reserved rights. To claim that an individual nevertheless has a duty to abide by judicial decisions concerning the extent of these rights is to give to the judiciary the very same absolute despotic power that Blackstone gives to the legislature. This is no closer to overcoming authoritarianism. The only means of ending authoritarianism is to empower citizens themselves to protect their rights as they see fit. This is the idea of auxiliary rights as I understand the term. The privilege against self-incrimination and the right to bear arms are examples of these rights.

\footnotetext{
55. Id.

56. Id. at $* 138$.

57. Id. at $* 139$.

58. Id.
} 


\section{The PARADOX AND THE PRIVILEGE AGAINST SELF-INCRIMINATION}

The privilege against self-incrimination is an enigma. The law on its scope is universally recognized to be a hopeless muddle- "an inconsistent combination of difficult-to-justify broad rules and a hodgepodge of miscellaneous exceptions." ${ }^{59}$ Even the question of whether it serves any moral purpose has yet to be resolved. On the one hand, there is an enormous literature, going back at least to Jeremy Bentham, arguing that the privilege has no moral justification ${ }^{60}$ - that it is a "constitutional mistake" ${ }^{61}$ that "cannot be justified either functionally or conceptually." ${ }^{62}$ According to the critics, the privilege simply frustrates, for no good reason, the state's legitimate attempts to enforce criminal law.

And yet support for the privilege remains widespread and tenacious. Many take the privilege to be a moral axiom that reflects some

59. John Fabian Witt, Making the Fifth: The Constitutionalization of American SelfIncrimination Doctrine, 1791-1903, 77 TEX. L. REV. 825, 908 (1999); see also SUSAN EASTON, THE CASE FOR THE RIGHT TO SILENCE 207-35 (2d ed. 1998) (examining the tension between the privilege and the use of bodily samples in evidence); Amar \& Lettow, supra note 7, at 858 (criticizing case law on the privilege as incoherent); Stephen A. Saltzburg, The Required Records Doctrine: Its Lessons for the Privilege Against Self-Incrimination, 53 U. CHI. L. REV. 6, 7 (1986) ("The limitations [courts] invoke, although defensible, do not flow ineluctably from the history or language of the fifth amendment.").

60. 5 JEREMY BENTHAM, RATIONALE OF Judicial EVIDENCE 207-83 (Garland Publishing 1978) (1827); SIDNEY HOOK, COMMON SENSE AND THE FIFTH AMENDMENT 66-101 (1957); WALTER V. SCHAEFER, THE SuSPECT AND SOCIETY 59-76 (1967); Amar \& Lettow, supra note 7, at 889-98; Ian Dennis, Instrumental Protection, Human Right or Functional Necessity? Reassessing the Privilege Against Self-Incrimination, 54 CAMBRIDGE L.J. 342, 348-59 (1995); Dolinko, supra note 7, passim; Donald A. Dripps, Foreword: Against Police Interrogation-And the Privilege Against Self-Incrimination, 78 J. CRIM. L. \& CRIMINOLOGY 699, 711-18 (1988); Henry J. Friendly, The Fifth Amendment Tomorrow: The Case for Constitutional Change, 37 U. CIN. L. REV. 671, 679-95 (1968); Green, supra note 22, at 656-68; Charles T. McCormick, Law and the Future: Evidence, 51 Nw. U. L. REV. 218, 222 (1956); John McNaughton, The Privilege Against Self-Incrimination: Its Constitutional Affectation, Raison d'Etre and Miscellaneous Implications, 51 J. CRIM. L., CRIMINOLOGY \& POLICE SCI. 138, 142-51 (1960); Henry T. Terry, Constitutional Provisions Against Forcing Self-Incrimination, 15 YALE L.J. 127, 127-30 (1906); John H. Wigmore, Nemo Tenetur Seipsum Prodere, 5 HARV. L. REV. 71, 87 (1891); C. Dickerman Williams, Problems of the Fifth Amendment, 24 FordHAM L. REV. 19, 22-23 (1955); see also Palko v. Connecticut, 302 U.S. 319, 326 (1937) (Cardozo, J.) ("Justice . . . would not perish if the accused were subject to a duty to respond to orderly inquiry.").

61. Dripps, supra note 60, at 718 .

62. Dolinko, supra note 7, at 1147. Such criticisms generally do not extend to all protections that have been found to have their source in the privilege. A right of silence during custodial detention by the police (and right to be informed of this right) might be justified, even if the core protection of the privilege-the right of the criminal defendant to refuse to take the stand during trial-cannot be successfully defended. 
"of our fundamental values and most noble aspirations." ${ }^{63}$ The privilege, supporters argue, is tied "to the nature of a free man and to his relationship to the state. ${ }^{\circ 4}$

The irresolvable character of the debate over the privilege and the muddled case law on its scope are the result of the paradox of auxiliary rights. My goal is not to canvass all possible justifications of the privilege and show, on the basis of the historical evidence, ${ }^{65}$ that an auxiliary justification is the only viable one. The best I can do here is outline standard, instrumental, and auxiliary justifications and show how the latter best captures core intuitions that many people have in favor of the privilege. I then argue that, because of the paradox, the debate over the justifiability of an auxiliary privilege cannot be successfully resolved, and judicial attempts to determine its scope in a principled fashion cannot succeed.

\section{A. Standard-Right Justifications}

Like other provisions in the Bill of Rights, the privilege against self-incrimination creates a sphere of legal protection against certain actions by the government. Whereas the Fourth Amendment protects a citizen against being subjected to unreasonable searches and seizures, ${ }^{66}$ the privilege protects him against being "compelled in any criminal case to be a witness against himself." ${ }^{67}$ Because most provisions in the Bill of Rights are standard rights, it is common for defenders of the privilege to argue that the sphere of legal protection

63. Murphy v. Waterfront Comm'n, 378 U.S. 52, 55 (1964); see also GRISWOLD, supra note 14 , at 73 (stating that the privilege is "an expression of the moral striving of the community"); Fortas, supra note 6 , at $98-100$ (proposing that the privilege reflects the view that the individual and the state are equals).

64. United States v. Wade, 388 U.S. 218, 261 (1967) (Fortas, J., concurring in part and dissenting in part).

65. In fact, the legislative history on the privilege against self-incrimination is so sketchy that it is virtually useless in interpreting this right. See United States v. Balsys, 524 U.S. 666, 674 (1998) ("[T] here is no helpful legislative history."); LEONARD W. LEVY, ORIGINS OF THE FIFTH AMENDMENT 430 (2d ed. 1986) (stating that from 1776 to 1791 , legislative proceedings and other literature provide insufficient evidence of the rationale behind the privilege); Eben Moglen, The Privilege in British North America: The Colonial Period to the Fifth Amendment, in R.H. Helmholz et Al., The Privilege Against Self-Incrimination 109, 136-38 (1997) ("[T]he legislative history of the Fifth Amendment adds little to our understanding of the history of the privilege.").

66. U.S. CONST. amend. IV.

67. U.S. CONST. amend. V. 
created by the privilege has a scope equivalent to a reserved moral right. ${ }^{68}$

But standard-right justifications of the privilege have trouble making sense of the following simple fact: the privilege applies only when its protections are to one's advantage in connection with a criminal case..$^{69}$ If there is no possibility of criminal punishment, one may be compelled to speak. The problem is how a reserved moral right could exist only when it frustrated criminal punishment.

For example, although the Fourth Amendment can be used by a criminal defendant to frustrate the case against him, it does so as a side effect of protecting something that exists whether or not it has this effect-privacy. The Fourth Amendment is violated even by unreasonable searches or seizures that fail to uncover anything incriminating. ${ }^{70}$ That the Fourth Amendment frustrates criminal punishment is not a necessary condition for its application.

It is for this reason that the privilege cannot be understood as protecting privacy. The privilege can do nothing to prevent the compelled revelation of even very private facts, provided that their revelation is not self-incriminating. ${ }^{71}$ If protecting privacy were truly the

68. See David LubAn, LAWYers AND JusticE: An ETHICAL Study 194-97 (1988) (suggesting that the privilege protects the accused's rights to dignity and integrity); Robert Heidt, The Fifth Amendment Privilege and Documents-Cutting Fisher's Tangled Line, 49 Mo. L. REv. 439, 468 (1984) (proposing that the privilege rests upon Lockean individualism).

69. See Estelle v. Smith, 451 U.S. 454, 462 (1981) (stating that use of the privilege depends on the nature of the defendant's statement and "the exposure which it invites"); Marchetti v. United States, 390 U.S. 39, 53 (1968) (basing application of the privilege on whether there are real "hazards of incrimination"); Hoffman v. United States, 341 U.S. 479, 486 (1951) (noting that the privilege extends both to statements that would in themselves support a conviction and to statements that would furnish "a link in the chain of evidence" needed to convict).

70. See, e.g., Irvine v. California, 347 U.S. 128, 136 (1954) (stating that excluding incriminating evidence because of a Fourth Amendment violation "does nothing to protect innocent persons who are the victims of illegal but fruitless searches"); Akhil Reed Amar, Against Exclusion (Except to Protect Truth or Prevent Privacy Violations), 20 HARV. J.L. \& PUB. POL'Y 457, 463-64 (1997) (remarking that the benefits of the Fourth Amendment exclusionary rule are "upside down," because it helps the guilty, not the innocent); Christopher Slobogin, Why Liberals Should Chuck the Exclusionary Rule, 1999 U. ILL. L. REV. 363, 401 (arguing for the effective damages remedy because the exclusionary rule does not compensate innocent people whose Fourth Amendment rights are violated).

71. Despite the difficulties with privacy justifications of the privilege, the Supreme Court has occasionally suggested that the privilege protects "the right of each individual 'to a private enclave where he may lead a private life." Murphy v. Waterfront Comm'n, 378 U.S. 52, 55 (1964) (quoting United States v. Grunewald, 233 F.2d 556, 581-82 (2d Cir. 1956)); see also Couch v. United States, 409 U.S. 322, 327 (1973) (stating that the privilege "respects a private inner sanctum of individual feeling and thought and proscribes state intrusion to extract selfcondemnation"). For an attempt to see how far privacy can justify the privilege, see Greenawalt, 
purpose of the privilege, immunity statutes, which allow the state to compel testimony from those given immunity from prosecution, would be impermissible. ${ }^{72}$

In the end, all standard-right justifications of the privilege run into the same problem. Consider the argument that the privilege protects criminal defendants' autonomy. ${ }^{73}$ According to this justification, compelled self-incrimination is morally objectionable because it amounts to "self-condemnation on command." Although the state may try the defendant, the privilege shows that its "authority [is] not absolute: that it stop[s] short of the point where it might invade [his] mind and take dominion of his will."

supra note 6, at 20-26, 34-36. Not surprisingly, Greenawalt arrives at something less than the Fifth Amendment right. See id. at 59 ("As long as the trial court makes clear that silence is not itself proof of guilt, that the prosecution retains the burden of establishing guilt, and that the reasonable doubt standard must be met, I believe that restrained judicial comment inviting natural adverse inferences should be considered constitutionally acceptable.").

72. See Amar \& Lettow, supra note 7, at 890-91 ("A witness given immunity can be forced to testify about anything in his private enclave. This treatment stands in dramatic contrast to the true privacy privileges of wife-husband, priest-penitent, doctor-patient, lawyer-client, and so on, for which no such trumping exists."); William J. Stuntz, Self-Incrimination and Excuse, 88 COLUM. L. REV. 1227, 1234 (1988) (stating that if the privilege were designed to protect privacy, it would turn on the nature of the desired disclosure, not the consequences of disclosure). The privilege would also extend to testimony in civil cases and nontestimonial evidence in criminal cases, both of which often involve embarrassing matters.

73. See Barbara Allen Babcock, Fair Play: Evidence Favorable to an Accused and Effective Assistance of Counsel, 34 STAN. L. REV. 1133, 1138 (1982) ("Our tradition is to mistrust the state and create an area of autonomy for each individual, free from the government's malignant or benign interference."); Thomas S. Schrock et al., Interrogational Rights: Reflections on Miranda v. Arizona, 52 S. CAL. L. REV. 1, 49 (1978) ("The fifth amendment, standing for the high value placed on personal responsibility, rebukes government when, by omission or commission, it inhibits, stultifies, or interrupts the process by which the accused decides what to do about whatever criminal responsibility rests at his doorstep.").

74. Robert S. Gerstein, The Demise of Boyd: Self-Incrimination and Private Papers in the Burger Court, 27 UCLA L. Rev. 343, 349 (1979).

75. Fortas, supra note 6 , at 98 . Sometimes autonomy and privacy justifications of the privilege are connected. See Richard A. Wasserstrom, Privacy: Some Arguments and Assumptions, in Philosophical Dimensions OF PRIVACY 317, 322-23 (Ferdinand David Schoeman ed., 1984) ("[T] he fundamental point is that required disclosure of one's thoughts by itself diminishes the concept of individual personhood within the society."). Professor Robert Gerstein, for example, has defended the privilege on the theory that criminal defendants have a right to complete control over their revelations of remorse and self-condemnation. He argues that control over these revelations is significant because it allows defendants to assess their actions autonomously. See Gerstein, supra note 74, at 349 (stating that compelling revelations of remorse degrades the defendant by "interfer[ing] with the opportunity for autonomous moral development involved in coming to terms with [his] own wrongdoing, and denying [his] right to exclusive control of that development"); Robert S. Gerstein, Privacy and Self-Incrimination, 80 ETHICS 87, 91 (1970) ("It is not the disclosure of the facts of the crime, but the mea culpa, the public admission of the private judgment of self-condemnation, that seems to be of real concern.”); Robert S. Gerstein, 
The idea that citizens reserve the right to arrive at their own moral judgments is certainly plausible. But the privilege fails to correspond to this reserved right. Set aside the obvious fact that a state could improperly interfere with citizens' moral judgment other than by compelling testimony from them-for example, by brainwashing them or by limiting their access to the information and viewpoints that they need to arrive at their moral judgments in an autonomous and uncoerced fashion. ${ }^{76}$ Even if one concentrates on compelled testimony's alleged ability to make citizens turn their backs on their own moral beliefs and identify with the government, ${ }^{77}$ there is no reason to assume that this occurs only when the compelled testimony will result in criminal prosecution. Compelling an immunized co-conspirator to testify against her comrades or compelling a witness to testify against a criminal defendant with whom she sympathizes would be equally problematic. If the privilege protected one's moral judgment, then these people too would have rights of silence.

Punishment and Self-Incrimination, 16 AM. J. JURIS. 84, 88 (1971) ("We are, in compelling selfincrimination, weakening the very capacities for self-evaluation and regeneration that we rely upon for rehabilitation in punishment.”).

76. Professor Thomas Scanlon has argued that the First Amendment right to free expression protects autonomy by protecting access to such information and viewpoints. Thomas Scanlon, A Theory of Freedom of Expression, 1 PHIL. \& PUB. AfF. 204, $206-07$ (1972). Professor Scanlon has since changed his views on this matter in ways that are unrelated to my argument. T.M. Scanlon, Jr., Freedom of Expression and Categories of Expression, 40 U. PITT. L. REV. 519, 534 (1979) (faulting his earlier theory, the "Millian Principle," for its inability to take into account "variations in audience interests under varying circumstances" while maintaining that "[m]ost of the consequences of the Millian Principle are ones that [he] would still endorse.").

77. There are plenty of reasons to question whether compelled testimony really has the capacity to influence significantly one's moral judgment. Certainly defenders of the privilege, by speaking of compelled self-incrimination as "self-condemnation on command," see some analogy between self-incrimination and brainwashing. But nothing about the state's inquiries into the defendant's activities demands that she give up her moral judgment. The state wants her information, not her soul. See Dolinko, supra note 7, at 1130:

If a suspect or a defendant were legally obligated to give truthful answers to questions about the alleged crime, his interrogators ... would presumably want answers to the kind of factual questions that could establish his guilt... Why, then, should we believe that if the interrogators succeed in obtaining a confession, they must necessarily have elicited expressions of remorse and self-condemnation from the suspect (especially when that individual may not feel any remorse at all)?

Furthermore, even if the influence on the criminal defendant's moral judgment is as great as autonomy defenses suggest, it is not clear that the right of autonomy is violated by these influences. The fact that one's moral judgment is influenced by one's family and friends does not mean that one's autonomy is violated, and the same thing should be true of the state's influence on the criminal defendant during trial. Indeed, such influence cannot be more intrusive than rehabilitative punishment, which is not considered improper. $I d$. at 1128 ("The claim [that compelling self-incrimination is degrading] is incompatible with [the] advocacy of rehabilitation as a principal goal of the punishment of criminals."). 
What the privilege protects is not privacy or autonomy, but an instrument of self-defense. Silence is protected only when it can be used to defend oneself against punishment. For this reason, more sophisticated standard-right defenses of the privilege are based on the idea that criminal defendants have a reserved right to self-defense. The problem with such arguments, however, is how such a reserved right is compatible with the government's authority to adjudicate and punish violations of the law.

Consider, for example, Abe Fortas's argument that a state founded on the social contract "has no right to compel the sovereign individual to surrender or impair his right of self-defense," $"$ and that the individual has "the sovereign right to refuse to cooperate; to meet the state on terms as equal as their respective strength would permit; and to defend himself by all means within his power-including the instrument of silence." $" 7$

Fortas is correct that, according to Lockean social contract theory, there is a natural right of self-defense, in the sense that selfdefense is of value independently of its tendency, in the aggregate, to make other natural rights more secure. Indeed Locke's argument for the social contract is predicated upon the increased number of violations of natural rights that occur in the state of nature precisely because people have the right to defend their rights as they see fit. If self-defense were of value only to the extent that it protected natural rights, people would have a natural duty to give up their power to defend themselves as they see fit to an authority, regardless of their consent. ${ }^{80}$

But this natural right of self-defense cannot possibly justify a standard constitutional right, for two reasons. First of all, even in the state of nature, individuals do not have rights to defend themselves of the sort that could justify a right of silence that would be enjoyed by everyone suspected of a crime. For example, in the state of nature, someone who has violated natural rights may not defend herself against a reasonable level of punishment. ${ }^{81}$ By violating natural rights

78. Fortas, supra note 6, at 99.

79. Id. at 98 .

80. $C f$. David Schmidtz, The Limits of Government: An Essay on the Public GoOds ARGUMENT 38 (1991) (arguing that since one has a right to punish only by the least risky acceptable method, even independents remaining in the state of nature have to let the state punish for them).

81. LOCKE, supra note $16, \S \S 8,22,172,178,181$. Some defenders of the privilege appeal to Hobbes's argument that promises to the sovereign to relinquish one's right to self-defense are 
she has forfeited her natural rights. Having forfeited these rights, she has no ground for defending herself and thus no natural right to silence.

Accordingly, if there is a right to silence in the state of nature, it is a right that only the innocent possess. ${ }^{82}$ There is no general natural right to silence, like the general right to privacy, that even the guilty enjoy. And without a general right to silence, there is no standardright justification of the privilege.

Furthermore, those entering civil society would alienate even their right to defend themselves against punishment when they were

not binding. Thomas HobBes, Leviathan 114 (J.M. Dent \& Sons Ltd. 1983) (1651) ("If a man be interrogated by the Soveraign, or his Authority, concerning a crime done by himselfe, he is not bound (without assurance of Pardon) to confesse it; because no man . . can be obligated by Covenant to accuse himselfe."); id. at 72 ("A Covenant to accuse ones selfe, without assurance of pardon, is ... invalide."); see Communist Party of the United States v. Subversive Activities Control Bd., 367 U.S. 1, 180 (1961) (Douglas, J., dissenting) (describing Hobbes as a defender of the privilege); Phelps v. Duckworth, 772 F.2d 1410, 1417 (7th Cir. 1985) (Posner, J., concurring) (same); Heidt, supra note 68, at 468-69 (same); Sanford Levinson, Testimonial Privileges and the Preferences of Friendship, 1984 DuKE L.J. 631, 639 (same). Setting aside the fact that Hobbes held a most un-Lockean conception of governmental authority, he is not talking about a right of self-defense that could justify the privilege against self-incrimination. $\mathrm{He}$ does not argue that the sovereign has a duty to respect the right of the accused to engage in selfdefense, only that the accused has no duty to the sovereign to confess. Claire Oakes Finkelstein, On the Obligation of the State to Extend a Right of Self-Defense to Its Citizens, 147 U. PA. L. REV. 1361, 1388-90 (1999) ("The Sovereign has the rights that all persons have in a state of nature, and those rights are unlimited. The natural rights of citizens and the rights of the Sovereign can therefore conflict with one another, a point Hobbes repeatedly emphasizes ...."); Green, supra note 22, at 678-80 ("[T] he most Hobbes could ever show is that the defendant and the sovereign are at war with each other, and that either side may use whatever means are at his disposal to prevail without violating the rights of the other."); Jeremy Waldron, Self-Defense: Agent-Neutral and Agent-Relative Accounts, 88 CAL. L. REV. 711, 732 (2000) ("Hobbes's doctrine of self-defense does not establish that it is wrong for a sovereign to convict, condemn, or punish a person for defending himself. His argument establishes only that a person has no obligation to submit to punishment."). For the same reason, Hobbes argued that condemned criminals may attempt to escape, HoBBES, supra, at 117, but that does not mean that he thought that the sovereign has a duty to let them escape. See Simmons, supra note 18, at 152 n.16 ("Lacking any correlative duty to respect my liberty right, another may be perfectly within her own rights in interfering with me."); Waldron, supra, at 728-29 ("The right of nature is certainly not correlated with anyone else's duty to permit or refrain from interfering with the subject's selfpreservation."). Indeed, Hobbes thought the sovereign had no duties to its citizens-it could not be accused of injustice even for putting the innocent to death. HOBBES, supra, at 112.

82. To be sure, compelling everyone in the state of nature, innocent and guilty alike, to participate at trial if they are suspected of wrongdoing would make the adjudication and punishment of rights violations more efficient. But under Lockean contractarian principles, only individual consent, and not these positive consequences, could justify the imposition of this burden. Green, supra note 22, at 686-90. For a similar argument, see ROBERT NOZICK, ANARCHY, STATE AND UTOPIA 102 (1974) (arguing that a person not subject to the state has the right to remain silent at trial if he is innocent of wrongdoing). 
innocent. ${ }^{83}$ For it is only by alienating this right that the government is given the authority to adjudicate their guilt. If citizens reserved this right, the government would be permitted to punish criminal defendants only if they were actually guilty of natural rights violations, not if the government came to the legal conclusion that they were guilty. Every criminal defendant would simply escape the authority of the state if she had done nothing wrong. And that is not the Lockean position. $^{84}$

As a result, within civil society even criminal defendants who are innocent of wrongdoing would have no reserved right of silence. The only time that a criminal defendant would have such a right is if the state were acting outside of its authority, that is, if it failed to protect other reserved rights of the defendant. But to argue that the privilege exists to handle this contingency is to argue that it is an auxiliary, not a standard, right.

The popular argument that compelled self-incrimination violates the defendant's right not to be subjected to the "cruel trilemma of self-accusation, perjury or contempt ${ }^{\text {"85 }}$ is, in the end, equivalent to a

83. Cf. Richard A. Posner, An Economic Approach to the Law of Evidence, 51 STAN. L. REV. 1477, 1534 (1999) (proposing that people choosing principles of criminal procedure from behind a veil of ignorance would not include the privilege). That even innocents have a moral duty to submit to punishment is expressed in the criminal law. Those prosecuted for escaping from prison may not bring up their innocence as a defense, but only lack of governmental authority to adjudicate guilt. They must show that the conviction is wholly without law and so void. People v. Ah Teong, 28 P. 577, 578 (Cal. 1891); cf. State v. Brown, 571 A.2d 1367, 1371 (N.J. Super. Ct. App. Div. 1990) ("Irregularity in bringing about or maintaining detention, or lack of jurisdiction of the committing or detaining authority, shall not be a defense ... if the escape is from a prison or other custodial facility or from detention pursuant to commitment by official proceedings."). But see Robinson v. Boles, 142 S.E.2d 55, 57-58 (W. Va. 1965) (holding that denial of the right to counsel during trial is a valid defense for escape).

84. See LOCKE, supra note $16, \S 129$ (arguing that each citizen gives up the right of "doing whatsoever he thought fit for the preservation of himself" upon entry into civil society).

85. Murphy v. Waterfront Comm'n, 378 U.S. 52, 55 (1964). For sympathetic accounts of the cruel trilemma argument, see JosePH D. GRANO, CONFESSIONS, TRUTH AND THE LAW 39 (1993) ("[T]hose who defend the protection against compulsory self-incrimination may deem it cruel simply to force the individual to "partake in his own undoing."); Greenawalt, supra note 6, at 36 ("[W]e may hesitate to say that someone has a moral duty to bring conviction and imprisonment upon himself."); David W. Louisell, Criminal Discovery and Self-Incrimination: Roger Traynor Confronts the Dilemma, 53 CAL. L. REV. 89, 95 (1965) (stating that the best justification for the privilege is that it is "cruel to make a man an instrument of his own condemnation"). For criticism of the argument, see Amar \& Lettow, supra note 7, at 890 (1995) (stating that the argument "does not hold water"); Dolinko, supra note 7, at 1093 ("[Innocent witnesses] are often compelled to give evidence in situations that force upon them various other kinds of 'cruelly' difficult choices"); Stephen J. Schulhofer, Some Kind Words for the Privilege Against Self-Incrimination, 26 VAL. U. L. REV. 311, 318 (1991) (stating that the trilemma arises only for the guilty, and that "we do not permit people to escape hard choices that are a consequence of 
justification on the basis of a natural right of self-defense. The trilemma is different from what is faced by every subpoenaed witness, who will also receive sanctions for perjury or contempt, ${ }^{86}$ only because these sanctions compel criminal defendants, and do not usually compel witnesses, to act contrary to their interest in defending themselves against punishment. And that can be a violation of the defendant's rights only if there is a reserved right protecting this interest. But there is no such right. ${ }^{87}$

\section{B. Instrumental-Right Justifications}

If the scope of the privilege fails to correspond to any reserved right, the possibility still remains that the privilege is instrumental. Giving criminal defendants this right might protect reserved rights indirectly.

There are many reasons why the political community might condition its delegation of authority to a government on the existence of instrumental rights in the government's constitution. Consider once

their own voluntary decisions"); Stuntz, supra note 72, at 1237-39 (stressing that the cruelty rationale is flawed because witnesses, not just the accused, are also forced to make cruel choices).

86. GRANO, supra note 85, at 38; Vincent Martin Bonventre, An Alternative to the Constitutional Privilege Against Self-Incrimination, 49 BROOK. L. REV. 31, 54-55 (1982).

87. Another popular argument for the privilege is not that the defendant has a right to selfdefense, but that the desire to defend oneself is so overwhelming that the defendant should be excused from being placed in a position where she has a legal obligation to overcome it. The temptation of the defendant to lie on the stand is so overwhelming that she should not be required to take the stand at all. See CHARLES TILford MCCORMICK, MCCORMICK ON EVIDENCE § 118, at 287 (Edward W. Cleary ed., 3d ed. 1984) (suggesting that placing a person in a position in which he might lie, then punishing him for lying, is intolerable); Stuntz, supra note 72, at 1242-92 (arguing that the current view of duress and necessity should be expanded and merged to create "a general principle of situational excuse" that justifies the privilege); Lane V. Sunderland, Self-Incrimination and Constitutional Principle: Miranda v. Arizona and Beyond, 15 WAKE FOREST L. REV. 171, 179-82 (1979) (“[T]he veracity issue notwithstanding . . . forcing an individual charged with a crime 'to choose among the three horns of the triceratops-harmful disclosure, contempt, perjury'-is inhumane according to the modern understanding of human nature.") One problem with the argument from excuse is that it threatens to expand the privilege's scope excessively. If perjury is really excusable, then why not other forms of self-defense, for example, destroying evidence, resisting arrest, or escaping from prison? See Dolinko, supra note 7, at 1097 ("It may be 'only natural' to conceal evidence that would subject one to criminal punishment, yet we do punish suspects and defendants for destroying evidence, suborning perjury, or otherwise seeking to cover up their wrongdoing."). In addition, it is doubtful that perjury is inevitable. By punishing perjurious defendants who are convicted more than those who confess, one can make self-incrimination a psychological possibility for a defendant. Indeed, that is the whole point of compelling self-incrimination. An argument from excuse is most plausible in cases in which those who confess are put to death-which is rare precisely because no incentive to confess is thereby created. And even without such incentives, confession is not psychologically impossible. Many criminals repent of their crimes. 
again the right to a trial by jury. The political community would have a reason to insist upon this constitutional right, even if the reserved moral right to a reasonable and impartial factfinder had been protected by a standard right like the Due Process Clause, if it feared that the government would often be unable to tell whether a factfinder was reasonable and impartial. An indirect instrument is the best way of assuring that this reserved right is respected in the face of governmental ignorance.

Another reason for instrumental rights is the possibility of governmental failure to give standard rights their genuine legal force. The political community, recognizing that governments can make such mistakes, might demand a second line of defense for reserved rights in the form of a constitutional right that indirectly protects reserved rights.

But what reason is there to believe that giving criminal defendants the ability to defend themselves against punishment would indirectly protect reserved rights in the face of governmental ignorance or mistake? One possibility is that criminal defendants would generally use the right of self-defense only when their reserved rights were actually violated. But even if one assumes, implausibly, that criminal defendants use the privilege only when they think their reserved rights are violated, there remains the Lockean principle that they would tend to interpret the scope of their own rights too broadly. Criminal defendants will simply read their reserved rights in a way that justified self-defense. The result will not be a coherent alternative to the government's protections for reserved rights that could correct its mistakes, but only the chaos of the state of nature. Most of the time the privilege would simply frustrate legitimate laws, such as those prohibiting murder and rape, that do not violate reserved moral rights. $^{88}$

\footnotetext{
88. BENTHAM, supra note 60 , at 237 :

[B]y the effect of this impunity-giving rule, undue suffering has probably in some instances been prevented. Prevented? but to what extent? To the extent of that part of the field of penal law which is occupied by bad laws .... Applying with equal force and efficiency to all penal laws without distinction, to the worst as well as to the best, it at the same time diminishes the efficiency of such as are good ....
}

Another reason to question whether the privilege is a proper instrument for the protection of reserved rights is that even in those cases where it is properly employed, it frustrates only one limited form of evidence gathering in connection with offensive laws. HoOK, supra note 60, at 63; 8 John H. WigmORE, EvidENCE $§ 2251$, at 313 (McNaughton rev. 1961); Dolinko, supra note 7, at 1086-87 (describing privilege as "egregiously overinclusive and patently underinclusive"). 
But some instrumental justifications of the privilege are based on the idea that it can indirectly protect reserved rights despite criminal defendants' tendency to use it in a purely self-interested fashion. For example, some have argued that the privilege protects reserved rights of conscience or free speech by frustrating the enforcement of laws that violate these rights. It performs this function because evidence that these laws have been violated tends to come from the defendant's own mouth. ${ }^{89}$

The most common instrumental argument for the privilege along these lines is that it protects a defendant's reserved right to a system of adjudication that reliably separates the guilty from the innocent. ${ }^{90}$ In its traditional form this argument is that the privilege prevents the conviction of innocent but nervous defendants who might do poorly on the stand. ${ }^{91}$ A more sophisticated version is that the privilege, by encouraging guilty defendants to opt for silence, allows innocent defendants to signal their innocence through their willingness to take the stand. Denying defendants the privilege would induce guilty defendants to move from silence to false exculpatory statements, thereby reducing the credibility of exculpatory statements by the innocent. $^{92}$

It is difficult to accept or reject definitively arguments that the privilege makes factfinding more reliable. ${ }^{93}$ But it is significant that

89. Alan Donagan, The Right Not to Incriminate Oneself, Soc. PHIL. \& POL'Y, Spring 1984, at 143-47; see McNaughton, supra note 60, at 145-46 (examining the argument that the privilege protects First Amendment rights).

90. Murphy, 378 U.S. at 55 (stating that "the privilege, while sometimes 'a shelter to the guilty,' is often 'a protection to the innocent'” (quoting Quinn v. United States, 349 U.S. 155, $162(1955)))$.

91. See, e.g., Wilson v. United States, 149 U.S. 60, 66 (1893) ("Excessive timidity ... will often confuse and embarrass him to such a degree as to increase rather than remove prejudices against him."); Amar \& Lettow, supra note 7, at 900-01 (proposing that even the innocent, when flustered, may make seeemingly inculpatory statements); Alfred C. Clapp, Privilege Against Self-Incrimination, 10 RUTGERS L. REV. 541, 548 (1956) (stating that innocent defendants, if frightened, might "trip themselves over an inconsistency or contradiction" if on the stand); Schulhofer, supra note 85, at 327-33 (defending the privilege for its ability to protect the innocent on multiple grounds); Dorsey D. Ellis, Jr., Vox Populi v. Suprema Lex: A Comment on the Testimonial Privilege of the Fifth Amendment, 55 IOwA L. REV. 829, 846 (1970) (arguing that compelling the innocent to testify is cruel "because of the danger that the jury will convict him on the basis of his poor demeanor and performance").

92. See Green, supra note 22, at 646-48 (describing but ultimately rejecting this justification of privilege). A recent article that is devoted to this argument is Seidmann \& Stein, supra note 7.

93. One of the most important empirical questions standing in the way of assessing such arguments is whether juries draw adverse inferences from a defendant's silence. Such adverse 
defenders of the privilege generally believe that it is morally justified despite frustrating the truth-seeking functions of the trial. They defend it just as much when factually guilty defendants alone benefit from its exercise. ${ }^{4}$ For this reason, the Supreme Court has rejected arguments that the privilege increases the probability that the innocent will be acquitted, ${ }^{95}$ and academic debate has revolved around other arguments. ${ }^{96}$

Indeed this resistance to instrumental justifications of the privilege is more general. Defenders of the privilege tend to believe that its moral justification is invulnerable to empirical counterargument of the type to which instrumental rights are subject. Instead, the privilege, like the Fourth Amendment, protects something that has value in itself, independently of its instrumental effects. ${ }^{97}$ It is for this reason that standard-right defenses of the privilege are so common, despite the difficulties that they face.

inferences are obviously possible notwithstanding constitutional requirements, under Griffin $v$. California, 380 U.S. 609 (1965) and its progeny, that juries not draw such inferences. On the problem of adverse inferences for instrumental argument for the privilege generally, see Dolinko, supra note 7, at 1074-75. On the inability of the signaling argument to work if juries draw such inferences, see Green, supra note 22, at 646-48. For evidence that juries do draw adverse inferences, see $i d$. at 642-43 n.51 (citing articles). Professors Daniel Seidmann and Alex Stein offer as evidence that jurors do not draw adverse inferences the fact that, after the passage in England of the Criminal Justice and Public Order Act, 1994, c. 33, §§ 34-38 (Eng.), which allowed adverse inferences from silence, the rate at which defendants responded to interrogation in the police station and testified at trial increased. This change suggests that factfinders were not drawing adverse inferences when they were legally prohibited from doing so. Seidmann \& Stein, supra note 7, at 484-95, 501-02 (citing TOM BUCKE ET AL., THE RIGHT OF SILENCE: THE IMPACT OF THE CRIMINAL Justice AND PUBliC ORder ACT OF 1994 (2000)). The evidence concerning analogous changes in Singapore is, however, to the contrary. After adverse inferences were allowed, the already small percentage of defendants who remained silent actually increased. Meng Heong Yeo, Diminishing the Right to Silence: The Singapore Experience, 1983 CRIM. L. REV. 89, 96-99.

94. See Dolinko, supra note 7, at 1066-67 (stating that recent discussions of the privilege are partial to "individual rather than systemic rationales"); Seidmann \& Stein, supra note 7, at 435-36 (examining arguments based on rights such as privacy, individualism, and free agency).

95. Tehan v. United States, 382 U.S. 406, 413-15 (1966); see also Allen v. Illinois, 478 U.S. 364, 375 (1986) ("The privilege against self-incrimination ... is not designed to enhance the reliability of the factfinding determination.”).

96. See Dolinko, supra note 7, at 1066-67 (noting that authors in recent discussions have tended toward rights-based reasoning, perhaps in response to the "vacuous, rhetorical nature" of past reliance on systemic rationales).

97. See supra notes 71-79 and accompanying text. 


\section{Auxiliary-Right Justifications}

An auxiliary-right approach to the privilege nicely captures these intuitions. As I have already illustrated, auxiliary rights are easily confused with standard rights. ${ }^{98}$ Like a standard right, an auxiliary privilege would not be justified by its instrumental effects, but because it directly protects a reserved natural right, namely, the right to engage in self-defense when one's other reserved rights are violated. It would not matter that, in the aggregate, exercise of this right failed to increase the likelihood that reserved rights would be protected. Unlike a standard right however, the scope of an auxiliary privilege would fail to correspond with the scope of any moral right that could be legitimately exercised by all those who assert the privilege. It is simply false that all criminal defendants may justifiably engage in selfdefense against punishment. Only those whose rights have been violated by the government may legitimately use silence to defend themselves. ${ }^{99}$ But because the government cannot selectively provide the privilege only to those whose resistance to its laws it believes is legitimate without asserting absolute authority, rights of self-defense are provided to all criminal defendants, regardless of the merits of their resistance.

An auxiliary privilege can also be confused with an instrumental privilege that corrects governmental ignorance or mistake, for both rights are about protecting reserved rights when the government fails to do so. But according to an auxiliary-right interpretation, the purpose of the privilege is not that, in the aggregate, it will increase the chances that reserved moral rights will be protected. Its reason for existence is that it directly protects citizens' reserved right to defend themselves as they see fit when the government has violated their other reserved rights, in a manner unlimited by considerations of its long-term effects.

Consider the example of the privilege's invocation before the House Un-American Activities Committee, which is inevitably pointed out as a paradigmatic example of the privilege fulfilling its moral purpose. ${ }^{100}$ On the one hand, defenders of the privilege might be drawn to this example because they accept the argument that the privilege, in the aggregate, tends to protect reserved rights to free

\footnotetext{
98. See supra Section I.B.

99. See supra notes $82-84$ and accompanying text.

100. See GRISWOLD, supra note 14, at 10-13, 14-18 (defending the privilege against selfincrimination in light of McCarthy-era anticommunism); Fortas, supra note 6, at 101-04 (same).
} 
speech. On the other hand, the question of the privilege's long-run effects might be irrelevant. The point of the example could instead simply be that without the privilege, this legitimate defense of free speech would have received no legal protection. As a result, the government would have been asserting absolute authority over the criminal defendant - an authority unconstrained by reserved rights.

I believe that the auxiliary-right argument stands behind many intuitions in favor of the privilege. Consider the following argument by Professor Kevin Reitz:

The suspect's passivity is tolerated ... because we hold deep-seated doubts concerning the moral perfection of our criminal justice system, and we correspondingly respect the right of the individual accused to question the criminal law's application to him.... Skepticism of this kind is perhaps more strongly felt by a criminal suspect than by members of the general public, but its experience is not so limited. Americans have a profound and historic distrust for the use of governmental coercive power through the criminal process, and this perspective cannot be dismissed as an artifact of the eighteenth century. ${ }^{101}$

Professor Reitz argues that the privilege is a response to the possibility that the government's best efforts may nevertheless fail to protect reserved rights. But he offers no reason to believe that the privilege is a good method for correcting these mistakes. He cannot seriously be arguing that the criminal defendant's views are, in general, more likely to be correct than the government's. A foundational premise of Lockean social contract theory is that people tend to read their own rights too broadly. Each defendant will read her reserved rights in a manner that benefits her case. The result will not be a coherent alternative account of reserved rights that could function as a check on the government, but simply the anarchy of the state of nature-anarchy that increases the likelihood that individuals' natural rights will be violated.

So what does it mean for the privilege to be the product of "respect" for the criminal defendant's attempts to protect her reserved rights? I believe that Professor Reitz, like so many other defenders of the privilege, is arguing that the privilege is necessary to protect an avenue for legitimate civil disobedience. Unless the government gives

101. Kevin R. Reitz, Clients, Lawyers and the Fifth Amendment: The Need for a Projected Privilege, 41 DuKE L.J. 572, 582 (1991) (footnote omitted). 
the defendant a weapon to defend what she thinks are her reserved rights, the government's authority over the defendant is absolute. Of course, the government may give the defendant many legal entitlements - to due process, privacy, free speech, and so on. But if it may forbid her resistance if she believes that these rights are inadequate, its authority is still absolute. It has the authority to decide the limits of its authority, which is to say that its authority has no limits at all.

Abe Fortas's defense of the privilege can also be interpreted as an auxiliary-right argument. He argues that the privilege is a consequence of the Lockean view that "a sovereign state ... has no right to compel the sovereign individual to surrender or impair his right of self-defense." ${ }^{102}$ As I have demonstrated, this fails as a standard-right justification, since one has a natural right to defend oneself against punishment only if one is innocent-and even the innocent's right to self-defense would be alienated upon entering civil society. ${ }^{103}$ To enter civil society is to accept the state's authority to adjudicate and punish, which means accepting the state's decisions even if they are wrong.

And yet, to say that one alienates one's rights upon entering the social contract does not mean that this alienation is without limits. Locke makes it clear that it is not possible for an individual to give to the government the right to do with her whatever it wills. ${ }^{104}$ I cannot consent to be a slave, that is, someone who can be permissibly killed or harmed for any reason. ${ }^{105}$ And if unlimited political authority existed, I would be the government's slave-with only the rights that it chose to give to me.

There must be some reserved rights even within civil society. Although Locke himself is not that explicit about the extent of these reserved rights, he makes it clear that they follow from the fact that the alienation of natural rights is a voluntary decision made according to the self-interest of those leaving the state of nature. ${ }^{106}$ No one would consent to be a slave, because "no rational creature can be supposed

\footnotetext{
102. Fortas, supra note 6, at 99.

103. See supra notes $81-84$ and accompanying text.

104. LOCKE, supra note $16, \S \S 23,85,135,149,168,172,189$.

105. Id. $\S 17,22-23,91,149$; SIMMONS, supra note 18 , at 50 . The foundation for Locke's argument against voluntary slavery is the idea that "[n]obody can give more power than he has himself; and he that cannot take away his own life cannot give another power over it." LOCKE, supra note $16, \S 23$; see also id. $\S \S 24,135,149,168,172$. I cannot give someone the right to kill me, because I have no right to kill myself. I have no right to kill myself because I am, in essence, owned by God.

106. Id. $\$ \S 134,137$.
} 
to change his condition with an intention to be worse." ${ }^{1107}$ And if a citizen's reserved rights are violated, she reenters the state of nature and may reassert her natural right to defend herself, even if the aggregate effect of individuals' engaging in self-help is a reduction in the level of security for all.

So Fortas is right: there remains a reserved right of self-defense even in civil society. It is the natural right to resist the state when it exceeds its authority. And Fortas is also right that the privilege is necessary to protect this reserved right. It is not enough for the government to give expression to what it believes are the limits on its authority. If a government that believes that it has adequately protected reserved rights has no duty to give criminal defendants powers to resist its laws, then any claim that its authority is limited by reserved rights must ring hollow. Its authority cannot be limited by reserved rights if it has the authority to forbid individuals from protecting these rights. Without the privilege, no one is a citizen; everyone is a slave.

This explains why so many defenders of the privilege believe that without it the trial becomes a form of "debasement" nation of the self to the state." 109 It does not matter how solicitous the government is of the defendant's rights. Without the privilege the fact remains that the only views about reserved rights that matter are the government's. To avoid this, one must reintroduce the state of nature into the criminal trial, by allowing the defendant to maintain a "combative" or "adversarial" relationship. ${ }^{110}$

107. Id. § 131; see also id. $\S 137$ ("It cannot be supposed that [people] should intend ... to give to any one, or more, an absolute arbitrary power over their persons and estates ... . This were to put themselves into a worse position than the state of nature, wherein they had a liberty to defend their right against the injuries of others.").

108. United States v. Wade, 388 U.S. 218, 261 (1967) (Fortas, J., concurring in part and dissenting in part).

109. LUBAN, supra note 68, at 194.

110. This explains the tendency of defenders of the privilege to rely on martial metaphors. DAMAŠKA, supra note 10 , at 126 (stating that the privilege has its source in the idea that "a party to a contest should not be compelled to become telum adversarii sui, that is, an offensive weapon of his adversary"); 8 WIGMORE, supra note $88, \S 2251$, at 318 ("[The privilege] compl[ies] with the prevailing ethic that the individual is sovereign and that proper rules of battle between government and individual require that the individual ... not be conscripted by his opponent to defeat himself."); Fortas, supra note 6, at 98 ("The principle that a man is not obliged to furnish the state with ammunition to use against him is basic to this conception. Equals, meeting in battle, owe no such duty to one another, regardless of the obligations that they may be under prior to battle."); $c f$. John Griffiths, Ideology in Criminal Procedure or A Third "Model" of the Criminal Process, 79 YALE L.J. 359, 378-79 (1970) (drawing a relationship 
But just as protecting the criminal defendant's attempts at selfdefense is necessary to avoid absolutism, it is also incompatible with the authority of the state. One cannot give to the criminal defendant a right to resist the state only when her reserved rights are violated. ${ }^{111}$ One must instead give her the right to protect her rights as she sees fit. And in so doing, one has created an avenue for her to escape the state's legitimate authority. The privilege reintroduces the very anarchy that it was the job of the social contract to end. Instead of protecting reserved rights, it increases the likelihood that our natural rights will be violated.

It is not surprising, therefore, that critics of the privilege reject it as anarchistic. It is incoherent, they argue, for the government to apply the criminal law to the defendant, thereby manifesting its view that it has legitimate authority over her, while giving her an avenue to frustrate its exercise of this authority. ${ }^{112}$ The privilege is contrary to the "duty of citizenship," that is, the defendant's obligation to submit to the government's procedures for adjudicating and punishing crimes. ${ }^{113}$ To be sure, if she chooses to engage in civil disobedience by remaining silent on the stand, there may be little the government can do to compel her to speak. But because the government has the authority to forbid civil disobedience, she should expect not legal protection, but contempt sanctions.

\section{The Privilege's Incoherent Scope}

Virtually everyone agrees that the courts have been unable to delineate the privilege's scope in a conceptually satisfying way. The Supreme Court "zigs, zags, and balances, ad hoc." 114 The result is "an inconsistent combination of difficult-to-justify broad rules and a hodgepodge of miscellaneous exceptions. ${ }^{" 115}$ But the privilege's inco-

between adversarial criminal procedure, including the privilege against self-incrimination, and the "battle model," which conceives "of the criminal as a special kind of person who is the "enemy' of society, and of the trial as a battle in which (if guilty) he is vanquished"). For a more thorough discussion of the relationship between the privilege and the morality of warfare, see Green, supra note 22, at 706-12.

111. See supra pp. 125-26.

112. Dolinko, supra note 7, at 1144-45, 1126-27.

113. Amar \& Lettow, supra note 7, at 892 ; cf. Friendly, supra note 60, at 679-80 (contrasting the privilege with circumstances outside the courtroom in which " $[\mathrm{t}]$ hose who are questioned feel themselves to be morally bound to respond").

114. Amar \& Lettow, supra note 7, at 872.

115. Witt, supra note 59, at 908; see also EASTON, supra note 59, at 207-35 (criticizing the case law on the privilege as incoherent). 
herent scope is not the Supreme Court's fault. The fault lies with the paradox of auxiliary rights. This can be seen by considering one of the many puzzling distinctions employed in Fifth Amendment jurisprudence-the distinction between testimonial and nontestimonial evidence.

The privilege prohibits "compel[ling a person]" in any criminal case "to be a 'witness' against himself." Under current interpretations of the Fifth Amendment, one is compelled to be a witness only if compelled to produce evidence of a testimonial nature, that is, only if the compelled act "explicitly or implicitly, relate[s] a factual assertion or disclose[s] information." ${ }^{116}$ As a result, the privilege is not implicated by the government's seizure of a defendant's business records, because nothing about the seizure compels the defendant to perform a testimonial-or indeed any-act. And to the extent that she performed testimonial acts when creating the records, she did so voluntarily. ${ }^{117}$ Although she might have been a witness, she was not a compelled one.

In general, even requiring the defendant herself to turn over incriminating physical or documentary evidence will not implicate the privilege, because the act of turning over the evidence communicates nothing. Only if this act communicates something novel and selfincriminatory (for example, that the evidence is authentic) will she be able to take advantage of the privilege. ${ }^{118}$

116. Doe v. United States, 487 U.S. 201, 210 (1988).

117. United States v. Doe, 465 U.S. 605, 612 (1984) (holding that the defendant's business papers were not protected because they were voluntarily prepared). An unresolved wrinkle is whether this rule applies to private papers, something expressly left open by the Supreme Court. Fisher v. United States, 425 U.S. 391, 414 (1976). All but two circuits have accepted this natural extension of the theory. See, e.g., United States v. Hubbell, 167 F.3d 552, 567 (D.C. Cir. 1999) (per curiam), aff'd, 530 U.S. 27 (2000); Barrett v. Acevedo, 169 F.3d 1155, 1168 (8th Cir. 1999); United States v. Feldman, 83 F.3d 9, 14 (1st Cir. 1996); In re Grand Jury Subpoena Duces Tecum, 1 F.3d 87, 90 (2d Cir. 1993); United States v. Wujkowski, 929 F.2d 981, 983 (4th Cir. 1991); In re Grand Jury Proceedings, 759 F.2d 1418, 1419 (9th Cir. 1985). But see, e.g., In re Grand Jury Proceedings, 55 F.3d 1012, 1013-14 (5th Cir. 1995) (per curiam) (stating that the contents of personal papers may be protected by the Fifth Amendment); In re Grand Jury Proceedings, 632 F.2d 1033, 1043 (3d Cir. 1980) (same). The more complicated situation of the government's seizure of records that the defendant was required by law to generate can be ignored here. See, e.g., Marchetti v. United States, 390 U.S. 39, 48-60 (1968) (preventing the prosecution from using tax documents the defendant was required to keep under federal wagering tax statutes); Grosso v. United States, 390 U.S. 62, 67-68 (1968) (precluding the use by the prosecution of documents obtained from the defendant as a result of wagering excise tax provisions).

118. Fisher v. U.S., 425 U.S. 391, 410-13 (1976). 
There are good reasons to criticize the way the Supreme Court has applied this distinction. The Court has held, for example, that voice exemplars are nontestimonial, since it is only the phonetic character of the compelled speech, rather than the information conveyed by it, that is relevant. ${ }^{119}$ But to provide a voice exemplar is to choose one's own voice out of the infinite number of alternatives. One could, after all, choose one's best imitation of James Dean. This act of choice is testimonial because it informs that what one chooses is authentic.

By the same token, a defendant forced to present herself for identification by witnesses is compelled to perform a testimonial act because she is required to choose her own image over others. Admittedly, the defendant's ability to choose an inauthentic image is limited. The most she could do is scrunch up her face or affect a hunchback. Furthermore, in some cases, such as blood samples, the defendant simply may be unable to offer anything but the genuine article. But it is hard to see how compelling self-incrimination should become constitutionally permissible simply because the defendant finds it difficult to lie. Compulsion remains compulsion even if one has a limited ability to resist.

But the tortured details of the distinction between testimonial and nontestimonial evidence are not my concern here. The more fundamental question is why the distinction is relevant at all to the scope of the privilege. The locus classicus on this issue is Schmerber v. California, ${ }^{120}$ where the Court used the distinction to deny Fifth Amendment protections to criminal suspects compelled to provide blood samples.

The Schmerber Court explicitly declined to rely on the textual argument, which is unlikely to have succeeded anyway, ${ }^{121}$ that it simply follows from the meaning of the word that a "witness" provides testimonial evidence. ${ }^{122}$ It instead sought to explain this limit in terms of the moral rights the privilege protects. These rights included the criminal defendant's "dignity and integrity" and the "inviolability of the human personality" (that is, something like privacy and auton-

119. United States v. Hubbell, 530 U.S. 27, 34-35 (2000); United States v. Wade, 388 U.S. 218, 222-23 (1967); Gilbert v. California, 388 U.S. 263, 266-67 (1967).

120. 384 U.S. 757 (1966).

121. See Richard A. Nagareda, Compulsion "To Be a Witness" and the Resurrection of Boyd, 74 N.Y.U. L. REV. 1575, 1603-23 (1999) (critiquing the textual argument).

122. Schmerber, 384 U.S. at 761 n.6 ("[The decision] cannot turn on the Fifth Amendment's use of the word 'witness."'). 
omy), as well as his right, under "our accusatory system of criminal justice," to engage in self-defense by refusing to participate in the adjudication of his guilt. ${ }^{123}$ According to the Court, the privilege "demands that the government seeking to punish an individual produce the evidence against him by its own independent labors, rather than by the cruel, simple expedient of compelling it from his own mouth." ${ }^{124}$

But the Court admitted that if these moral rights were taken completely seriously, the privilege's scope would be unacceptably broad: "If the scope of the privilege coincided with the complex of values it helps to protect, we might be obliged to conclude that the privilege was violated." ${ }^{125}$ It justified setting aside these rights with respect to nontestimonial evidence, because a broader privilege carried excessive social costs. ${ }^{126}$

There is certainly nothing suspect about determining the scope of a constitutional right by looking to its costs. This is precisely how the scope of the Fourth Amendment is determined. As a standard constitutional right, the Fourth Amendment's scope is determined by looking to the scope of the reserved moral right that it protects. And the scope of the right of privacy is determined, in part, by the social costs of protecting intimate facts. ${ }^{127}$ Why is a police officer in hot pursuit of a suspect not forbidden under the Fourth Amendment from following the suspect into her home $?^{128}$ The reason is that her right of

123. Id. at 762 .

124. Id.

125. Id.; see also United States v. Wade, 388 U.S. 218, 245 (1967) (Black, J., dissenting in part and concurring in part) (positing that compelling a suspect to appear in a lineup and to speak certain words given him by the police violates the privilege); Schmerber, 384 U.S. at $772-$ 78 (Warren, Douglas, and Fortas, JJ., dissenting) (arguing that it was a violation of the petitioner's constitutional rights against self-incrimination to compel him to give a blood sample for the purposes of proving his guilt).

126. California v. Byers, 402 U.S. 424, 449 (1971) (Harlan, J. concurring in the judgment); Schmerber, 384 U.S. at 762-63; id. at 778 (Warren, J. dissenting); cf. Spevack v. Klein, 385 U.S. 511, 523-24 (1967) (Harlan, J., dissenting.) ("In federal cases stemming from Fifth Amendment claims, the Court has chiefly derived its standards from consideration of two factors: the history and purpose of the privilege and the character and urgency of the other public interests involved.").

127. See, e.g., New Jersey v. T.L.O., 469 U.S. 325, 337 (1985) (holding that the Fourth Amendment's scope is a question of balancing the individual's expectations of privacy against the government's need to keep public order); Stuntz, supra note 72, at 1236-37 (discussing the way courts balance an individual's privacy interest against the state's interests).

128. U.S. v. Santana, 427 U.S. 38, 42-43 (1976) (upholding warrantless entry and arrest because police were in hot pursuit and had probable cause to arrest suspect on drug charges); Warden v. Hayden, 387 U.S. 294, 298-99 (1967) (upholding a warrantless entry and arrest be- 
privacy does not extend that far, because the costs of respecting her interest in concealing intimate facts would simply be too great. It is not as if her right of privacy is simply ignored because of the costs; the scope of her right of privacy is determined by these costs.

But the consideration of social cost that gave rise to the testimonial/nontestimonial distinction in Schmerber cannot be understood along Fourth Amendment lines. First of all, if the scope of the privilege is a question of cost/benefit balancing, then courts should determine its scope by actually engaging in this balancing, not by fastening on the distinction between testimonial and nontestimonial evidence. To be sure, there is some merit to relying on rules of thumb, instead of figuring out the scope of a constitutional right on a case-by-case basis. Even in Fourth Amendment jurisprudence, general rules-for example, concerning trash cans and motor homes—are applied. ${ }^{129}$ But these are rough approximations of case-by-case balancing. And there is no reason-nor did the Schmerber court try to give a reason-to believe that the testimonial/nontestimonial distinction even roughly approximates case-by-case balancing. Given that the costs of protecting testimonial evidence are often great (a serial killer is put back on the streets who would be behind bars if the state could only compel her to take the stand at trial) and the benefits of refusing to protect nontestimonial evidence often negligible (the state may compel the defendant to turn over reams of documentary evidence that makes little difference to the success of its case), one would expect any rule of thumb to cut across the testimonial/nontestimonial divide. It is as if the Court, recognizing that balancing in Fourth Amendment cases was necessary, arbitrarily concluded that motor homes were entitled to unlimited Fourth Amendment protection and everything else got no protection at all.

It is for this reason that the distinction has been criticized as "lacking an organizing principle" 130 and as a form of "balancing without structure, [which] explains all results equally well; it is not so much a positive theory as a confession that no positive theory ex-

cause a delay in the investigation by the police would have gravely endangered their lives and the lives of others).

129. California v. Greenwood, 486 U.S. 35, 40-41 (1988) (holding that evidence disposed of in garbage cans will not be accorded the same level of privacy as evidence found in one's dwelling); California v. Carney, 471 U.S. 386, 392-94 (1985) (holding that evidence found in motor homes will not be accorded the same level of privacy as evidence found in one's dwelling).

130. Seidmann \& Stein, supra note 7 , at 475 . 
ists." ${ }^{131}$ It is not enough to know that $a$ line must be drawn. There must be some reason why the line is drawn where it is-a reason put in terms of the limits of the moral rights the privilege is supposed to protect.

But the Court failed to do justice to these moral rights, not because it was lazy or confused, but because it had no choice. On the one hand, the Court could not determine the scope of the privilege by looking to the scope of the defendant's rights to privacy or autonomy, for the privilege simply cannot be seen as protecting these rights. ${ }^{132}$ If it did, then there would be no reason to limit the scope of the privilege to testimony that was incriminating. The only option was to look to the defendant's right of self-defense.

But the only unalienated right to self-defense that the defendant has is the right to resist the state when it is violating her other reserved rights. If the privilege protects this right, then it is auxiliary. And if one did justice to this reserved right, the privilege's scope would take on anarchistic dimensions. Criminal defendants engaged in legitimate civil disobedience may do far more than remain silent at trial. They may decide not to turn over nontestimonial evidence (including blood samples), refuse to show themselves to witnesses, and, in all likelihood, escape from custodial detention and lie on the stand. Once one accepts that legitimate civil disobedience needs protection, there is no acceptable stopping point. Since this principled position is unacceptable, the Court had no choice but to settle upon a limitation that is unprincipled.

Of course, as the costs of protecting civil disobedience increase, they will become so intolerable that one will be compelled to draw a limit. But where one stops will not do justice to the right to civil disobedience, the way the Fourth Amendment's limits do justice to the right of privacy. One cannot justifiably say to the person prosecuted for being a Catholic that she may remain silent, but not refuse to turn over documents, because allowing her the latter right is "too costly." By reserving a right against religious discrimination, she also reserved the right to protect herself if she was discriminated against-no matter how inconvenient this might be for the government.

It is for this reason that Justice Fortas, although dismissing the distinction between testimonial and nontestimonial evidence as unrelated to the privilege's moral purposes, was himself compelled to

131. Stuntz, supra note 72 , at 1237.

132. See supra notes $71-77$ and accompanying text. 
draw his own arbitrary limit, to keep the privilege from taking on anarchistic dimensions:

[T] he exhibition of the person of the accused at a lineup is not itself a violation of the privilege against self-incrimination. In itself, it is no more subject to constitutional objection than the exhibition of the person of the accused in the courtroom for identification purposes. It is an incident of the State's power to arrest, and a reasonable and justifiable aspect of the State's custody resulting from arrest. It does not require that the accused takes affirmative, volitional action, but only that, having been duly arrested, he may be seen for identification purposes. ${ }^{133}$

Set aside the fact that exhibiting oneself in a lineup and in court involves a whole host of affirmative volitional acts, most notably the act of honest demeanor. Even if one were utterly passive in such cases, the question still remains why being compelled to be the passive source of evidence against oneself is outside the scope of the Fifth Amendment. If the Fifth Amendment exists to protect legitimate civil disobedience, then there is no reason why disobedience through refusal to present oneself in a lineup or in court should not also be protected. To say, as Justice Fortas does, that compelling a defendant to participate in a lineup is "a reasonable and justifiable aspect of the State's custody" is no explanation at all, but simply the same unprincipled "balancing" that the majority used in Schmerber. Since only an unacceptably broad scope for the privilege can be arrived at on principled grounds, an unprincipled balancing is the best that anyone can do.

The distinction between testimonial and nontestimonial evidence is far from being the only conceptually unsupported distinction employed, either explicitly or implicitly, in determining the privilege's scope. The Court has held, for example, that a jury must be instructed not to draw adverse inferences concerning guilt from the defendant's silence, because such adverse inferences are a "penalty ... for exercising a constitutional privilege." ${ }^{134}$ But juries are routinely allowed to draw positive inferences concerning those defendants who choose to

133. United States v. Wade, 388 U.S. 218, 259-60 (1967) (Fortas, J. concurring in part and dissenting in part).

134. Griffin v. California, 380 U.S. 609, 614 (1965); see also Carter v. Kentucky, 450 U.S. 288,305 (1981) (stating that a "no inference from silence" instruction is required by the Fifth and Fourteenth Amendments). 
testify, ${ }^{135}$ and forgoing this positive inference is just as much a deterrent to exercising the privilege as receiving an adverse inference. A distinction (between a penalty and the failure to provide a benefit) is drawn to keep the privilege's scope from expanding too far, but no reason for the distinction is available.

The literature on the privilege is filled with criticisms of this lack of clarity concerning its scope. ${ }^{136}$ Academics have repeatedly taken the courts to task for failing to assess the privilege's reach in the light of a coherent account of its moral purpose. The assumption, of course, is that this is possible. The problem is that it is not. In the next Part, I argue that the same problem arises concerning that other constitutional protection of self-defense: the Second Amendment.

\section{The PARADOX AND The RIGHT TO BEAR ARMS}

The Second Amendment is easily the most controversial provision in the Bill of Rights. Unlike the privilege, whose moral justification is primarily a matter of genteel academic debate, the controversy over the Second Amendment is played out in newspapers and political campaigns. But the intractable qualities of the two debates are similar. Just as critics of the privilege argue that it gives criminal defendants a tool to frustrate the government's legitimate attempts to adjudicate and punish crimes, critics of the Second Amendment argue that it gives individuals a tool to frustrate the government's legitimate attempts to reduce violence. ${ }^{137}$ Both argue that these rights incoherently reintroduce the state of nature into civil society. On the other hand, Second Amendment advocates are very much like defenders of

135. The constitutional permissibility of these positive inferences has been questioned only when there is a silent co-defendant who might be directly harmed through such comparisons. See, e.g., United States v. Petullo, 709 F.2d 1178, 1182 (7th Cir. 1983) (holding that a statement by counsel asking the jury only to draw favorable inferences from the defendant's willingness to testify need not be prejudicial to a co-defendant who did not testify); United States v. Hines, 455 F.2d 1317, 1334-35 (D.C. Cir. 1972) (holding that even though the defendant's counsel asked the jury to draw a favorable inference from the defendant's willingness to testify, such a statement was not inherently prejudicial to the silent co-defendant, and merely required judge's instruction); United States v. Blue, 440 F.2d 300, 302-03 (7th Cir. 1971) (permitting comments referencing the fact that a co-defendant took the stand, even though he was not required to do so); United States v. Hutul, 416 F.2d 607, 621-22 (7th Cir. 1969) (permitting the defendant's counsel to comment that he acted in good faith and was the only one of the defendants to testify in the case); 8 J. MOORE, MOORE's Federal PRACTICE II 14.04[2][c] (2d ed. 1981) (describing the positive inference as one of several ways in which one co-defendant's testimony can be deemed prejudicial to silent co-defendant).

136. See supra notes $114-15$ and accompanying text.

137. See infra notes $172-73$ and accompanying text. 
the privilege in believing that protecting self-defense is an essential constraint on governmental authority.

The irresolvable nature of the debate over the right to bear arms is due to the paradox of auxiliary rights. This is because the right to bear arms, like the privilege, is conceived of as auxiliary. As a result, the questions of its moral justifiability and scope will never be able to be resolved satisfactorily. The difficulty is not disagreement on political principles, for both supporters and critics of the right can each appeal to Locke. The problem is that the same Lockean principles generate persuasive arguments for and against the right.

Once again, my goal is not to canvass all possible justifications of the right to bear arms and show, on the basis of the historical evidence, ${ }^{138}$ that an auxiliary justification is the only viable one. All I can do here is outline the possible moral justifications (political, standard, instrumental, and auxiliary) and show how the latter best captures core intuitions held by many of its supporters.

\section{A. Political-Right Justifications}

Much academic debate concerning the Second Amendment has revolved around the argument that arms ensure the majoritarian trust through which a political community gives a government authority. They do this by giving the community the power to withdraw this trust through revolution. ${ }^{139}$ This is the right to bear arms as Blackstone conceived it, with the twist that the protection for majoritarianism is enshrined in a countermajoritarian constitutional right. ${ }^{140}$ Like the right to vote, the right to bear arms is a political right.

138. Although the legislative history of the Second Amendment is considerably more robust than the legislative history of the privilege, e.g., United States v. Emerson, 270 F.3d 203, 218-20 (5th Cir. 2001); MALCOLM, supra note 35, at 134-61; Bogus, supra note 12, at 322-75; David B. Kopel, The Second Amendment in the Nineteenth Century, 1998 BYU L. REV. 1359, passim, I will not discuss it here. My goal is making moral sense of the various interpretations of the Second Amendment that have been argued for on the basis of the historical record.

139. AMAR, supra note 32, at 47-49; Sanford Levinson, The Embarrassing Second Amendment, 99 YALE L.J. 637, 649 (1989); Lund, supra note 35, at 111-17; Brent J. McIntosh, The Revolutionary Second Amendment, 51 ALA. L. REV. 673, 679-81 (2000).

140. I will not spend time discussing those Second Amendment skeptics who question the likelihood that a tyrannical regime will arise, Bellesiles, supra note 8 , at 250 , as well as the usefulness of small arms as a means of resisting a tyrant who controls the military power of the United States. For discussion of these issues see Wendy Brown, Guns, Cowboys, Philadelphia Mayors, and Civic Republicanism: On Sanford Levinson's The Embarrassing Second Amendment, 99 YALE L.J. 661, 665 (1989); McIntosh, supra note 139, at 696; Elaine Scarry, War and the Social Contract: Nuclear Policy, Distribution, and the Right to Bear Arms, 139 U. PA. L. REV. 1257, 1268-86 (1991). 
So understood, the right does not protect, either directly or indirectly, natural rights that individuals have reserved against the political community. It instead protects the political community itself against a tyrannical minority. ${ }^{141}$ As a result, it need extend only as far as is necessary to allow one to engage in a popular revolt. It would not be a flaw in an interpretation of the Amendment's scope that it failed to put guns in the hands of citizens for self-defense. ${ }^{142}$ A law that required all ammunition to be kept in a sealed container that could be broken only in the event of a popular rebellion and for no other reason (even if a violent intruder invaded one's home) would stand a good chance of passing constitutional muster.

Many Second Amendment advocates resist political-right interpretations, precisely because they fail to protect the use of arms in self-defense. ${ }^{143}$ They argue that, like other provisions in the Bill of Rights, the Second Amendment exists to protect the reserved moral rights of individuals against the political community. To use the (somewhat unfortunate) terms within which this debate is often framed, it is an individual and not merely a collective right.

Speaking of the right to bear arms as an individual right can be misleading. The dispute between individual- and collective-right interpretations is not a dispute about whether individuals have standing to assert Second Amendment claims. To be sure, some courts have accepted arguments that states alone have standing to invoke the right, because, they argue, it exists solely to assure that state militias remain armed. ${ }^{144}$ But there is nothing about a collective-right interpretation of the Second Amendment as I have understood it that would deny individuals standing to assert the right. This can be seen by comparing the Second Amendment with another political right—the

141. See supra notes 57-58 and accompanying text.

142. See AMAR, supra note 32, at 47-49 (arguing that the right to bear arms was intended to be interpreted within the context of popular revolution); Akhil Reed Amar, Forward: The Document and the Doctrine, 114 HARV. L. REV. 26, 127 (2000) ("Intratextually, when the Constitution speaks of 'the people' rather than 'persons,' the collective connotation is primary. 'We the People' in the Preamble, establish the Constitution as public citizens meeting together in conventions and acting in concert, not as private individuals.").

143. See Brannon P. Denning, Gun Shy: The Second Amendment as an "Underenforced Constitutional Norm,” 21 HARV. J.L. \& PUB. POL'Y 719, 730 (1998) (describing how many Second Amendment opponents have used the "political right" interpretation as a way to deny standing to Second Amendment claimants); Nelson Lund, The Past and Future of the Individual's Right to Bear Arms, 31 GA. L. REV. 1, 31 n.72 (1996) (disputing interpretions of the Second Amendment as solely a political right to insurrection).

144. E.g., Hickman v. Block, 81 F.3d 98, 100-01 (9th Cir. 1996). In this Article, I assume that a states-right interpretation of the Second Amendment is wrong. 
right to vote. Although the right to vote is also collective in the sense that it exists to ensure that the government retains the political community's trust, it would be absurd to say that, for that reason, only the political community or the states-and not the individual-have standing to invoke the right.

Likewise, it should not be taken to follow from the collectiveright approach that the Second Amendment does not give each individual a legal entitlement to bear arms when a more restrictive distribution of arms can ensure that the political community's voice is heard. It is true that Professor Akhil Amar, one of the most prominent defenders of the collective-right interpretation, has argued that the purposes of the Second Amendment might be satisfied simply by ensuring that the armed forces are representative of the general population. ${ }^{145}$ But that is like saying that purposes of the right to vote might be satisfied by giving the members of those same representative armed forces exclusive authority to determine who holds governmental power. Simply because the right to bear arms exists to ensure that the political community's voice is expressed does not mean that individuals should not be given the entitlement to participate in the creation of that voice.

The issue is instead whether the use of arms in defense of individual rights against the political community is within the scope of the Second Amendment. Most Second Amendment advocates believe that it is. In particular, they believe that the right to bear arms protects individuals' natural rights to self-defense. ${ }^{146}$ But, as I illustrated earlier, such an argument can be interpreted in either a standard-, instrumental-, or auxiliary-right fashion. ${ }^{147}$

\section{B. Standard-Right Justifications}

By speaking of the right to bear arms as protecting a "natural right" to self-defense and self-preservation, which cannot be alienated upon entering civil society, Second Amendment advocates strongly suggest that they believe that self-defense by arms, like privacy, has noninstrumental value and that one reserves this right to self-defense by arms upon entering the social contract. ${ }^{148}$

145. Amar, supra note 142, at 126-129.

146. See infra note 148 and accompanying text.

147. See supra notes 33-35 and accompanying text.

148. See MALCOLM, supra note 35, at 119-20, 162 (arguing that the right to bear arms was understood only within the context of the right to self-defense); Roland H. Beason, Commen- 
The first step in assessing this argument is determining whether citizens actually have natural rights to use arms in self-defense. If citizens do not, then they could not possibly have reserved these rights upon entering civil society.

If citizens do have a natural right to use arms in self-defense, it cannot be the right to use arms whenever it is necessary to protect themselves from harm, but only when it is necessary to protect their other natural rights. For example, if someone enters my house with the manifest intent to kill me, I have a natural right to protect myself, but the intruder has no such natural right to defend herself against me. ${ }^{149}$ I have a right to self-defense because my right to life has been violated. ${ }^{150}$ The intruder has no right to self-defense, because I am not violating her right to life. ${ }^{151}$ But such limitation on the natural right to

tary, Printz Punts on the Palladium of Rights: It Is Time to Protect the Right of the Individual to Keep and Bear Arms, 50 ALA. L. REV. 561, 569-71 (1999) (stating that the Founders relied on the ideas of a natural right to self-defense and self-preservation in wording the Second Amendment); Anthony J. Dennis, Clearing the Smoke from the Right to Bear Arms and the Second Amendment, 29 AKRON L. REV. 57, 73-75 (1995) (arguing that the right to bear arms was understood only within the context of the right to self-defense); Don B. Kates, Jr., Gun Control: Separating Reality from Symbolism, 20 J. CONTEMP. L. 353, 363-64 (1994) (arguing that the Founders believed that the right to bear arms was not only of social value, it was a "sacred personal right"); Don B. Kates, Jr., Handgun Prohibition and the Original Meaning of the Second Amendment, 82 MicH. L. REV. 204, 230 (1983) [hereinafter Kates, Handgun Prohibition] (arguing that the Founders drafted the Second Amendment in light of their belief that self-defense is an inalienable right); Kates, supra note 35, at 102 (describing the "self defense origins of the second amendment" as "many and complex"); Lund, supra note 143, at 13-14 \& n.34, 59 (arguing that the Framers believed in an "individualistic" theory of the right to bear arms); Lund, supra note 35, at 117-21 ("Certainly the existence of a protected individual interest in the means to self-preservation follows at least as reasonably from the text and history of the Constitution as do the general rights of privacy and self-expression."); David E. Murley, Private Enforcement of the Social Contract: Deshaney and the Second Amendment Right to Own Firearms, 36 DuQ. L. REV. 827, 854-55 (1998) ("Locke, like Hobbes, recognized that no agreement with the sovereign could waive the right of self-defense."); L.A. Powe, Guns, Words, and Constitutional Interpretation, 38 WM. \& MARY L. REV. 1311, 1393-97 (1997) ("At the time of the Framing, selfdefense was perceived as an important individual right."); Robert Shalhope, The Ideological Origins of the Second Amendment, 69 J. AM. HIST. 599, 604-12 (1982) (discussing the libertarian themes in early American attitudes toward the individual right to bear arms).

149. For a discussion of Locke's account of self-defense, see Waldron, supra note 81, at 73337.

150. LOCKE, supra note $16, \S \S 16-18$. I set aside more complicated problems of self-defense against those who threaten one's life innocently. These situations are discussed in NozICK, supra note 82, at 34-35; JUDITH JARVIS THOMSON, THE REALM OF RIGHTS 370 (1990); Larry Alexander, A Unified Excuse of Preemptive Self-Protection, 74 NotRE DAME L. REV. 1475, 1482 (1999); Larry Alexander, Self-Defense, Justification, and Excuse, 22 PHIL. \& PUB. AFF. 53, 54 (1993); Finkelstein, supra note 81, at 1369-72; Judith Jarvis Thomson, Self-Defense, 20 PHIL. \& PuB. AFF. 283, 287-88 (1991).

151. LOCKE, supra note 16 , $\S \S 16-18$. 
self-defense is unlikely to be objected to by Second Amendment advocates, who recognize that an individual right to bear arms would protect only the use of arms in legitimate defense of one's rights. ${ }^{152}$

A more serious concern is whether it follows from my natural right of self-defense that I have a natural right to possess arms to defend myself. ${ }^{153}$ The possession of arms, after all, imposes risks upon others. Like any dangerous instrumentality, arms may cause unjustifiable harm, whether through mistake or malicious intent. And since I am examining the viability of a standard argument for the right to bear arms, I cannot assume that arms in fact decrease the risk of unjustifiable harm. For that is to argue that the right to bear arms is instrumental. To determine whether people have natural rights to possess arms, therefore, one must answer the questions of what risk of harm they may impose upon one another in the state of nature and what someone exposed to a high level of risk may do to protect herself.

Assume that someone in the state of nature keeps a collection of machine guns to protect herself from harm. It is not impossible that she could use them in justifiable self-defense. But her collection imposes risks of improper or accidental use upon others. What rights do those exposed to these risks have? Is their only protection a right to compensation or punishment if these risks materialize? Or do they have a right against her possessing these weapons in the first place, a right that allows them to take preemptive action? ${ }^{154}$

I believe that the only right they have is to ex post compensation or punishment. Requiring everyone to relinquish their machine guns because everyone would thereby be made safer seems no different from requiring everyone to relinquish their right to adjudicate and punish rights violations to a governmental authority, on the grounds that a reduction in feuding and an increased efficiency in the enforcement of natural law would result. If the reduction of mutually

152. E.g., Lund, supra note 143 , at $64-65$ :

Illegitimate violence comes about in three main ways: (1) an individual procures a gun in order to use it in crime; (2) an individual procures a gun for a legitimate purpose, but ends up misusing it spontaneously; and (3) a gun obtained for legitimate purposes kills or injures someone through accident.

153. To be sure, the possession of arms can be a natural right insofar as they are one's property. But the right to bear arms must protect the possession of arms over and above the protections provided for one's property in general. It must prohibit the regulation of arms under those circumstances where other property could be regulated.

154. For a pathbreaking discussion of this problem from someone in the natural rights tradition, see NOZICK, supra note 82, at 54-87. 
imposed risk were enough to justify imposing such restrictions in the state of nature, everyone would have a natural duty to submit to governmental authority, regardless of consent. ${ }^{155}$ The idea that everyone has such a natural duty is incompatible with Lockean individualism.

The same point is true not merely concerning the riskiness of the weapons I use to defend my rights, but also the riskiness of the investigative methods I use to determine whether self-defense is necessary. Assume that I meet someone in the middle of the wilderness. She looks at me in a suspicious way, and her hand moves slightly toward her waist. I respond by shooting her dead. Have I violated natural law? I believe that the answer is the following: if she was reaching for a gun, my actions were in keeping with natural law; if she was trying to scratch a mosquito bite, I have violated natural law. For someone to argue against my actions simply on the basis of the fact that they were unreasonable-that is, that the aggregate effect of such acts of self-defense will decrease everyone's security-I can respond that, under natural law, I may defend my rights as I see fit. That does not mean that I may defend myself against those who are not, in fact, violating my rights. It simply means that no one may restrict my attempts at self-defense simply because of the risk that they will go wrong. The only right anyone has in the state of nature is the right to punish me if my attempts at self-defense turn out to be improper.

Therefore, there is a natural right to bear arms and to use those arms in legitimate self-defense-a right that does not depend upon instrumental arguments about whether arms increase the level of security in society. The possession and use of arms has intrinsic, noninstrumental moral value on the basis of Lockean principles of autonomy and individualism. ${ }^{156}$

Accordingly, there are natural rights to use arms in self-defense that could be reserved upon entering civil society. But the idea that individuals would reserve these rights is nevertheless contrary to core Lockean principles. ${ }^{157}$ Return to the argument, which arose in my dis-

155. Cf. SCHMIDTZ, supra note 80 , at 38 (arguing that since one has a right to punish only by the least risky acceptable method, even independents remaining in the state of nature have to let the state punish for them).

156. George P. Fletcher, A Crime of Self-Defense: Bernard Goetz and the LAW ON TRIAL 32-33 (1988).

157. Some Second Amendment advocates, like some supporters of the privilege against selfincrimination, appeal to Hobbes's argument that the right of self-defense cannot be alienated. HoBBES, supra note 81, at 165. For such arguments, see Lund, supra note 35, at 119; Randy E. Barnett \& Don B. Kates, Under Fire: The New Consensus on the Second Amendment, 45 
cussion of the privilege, that individuals entering civil society alienate their rights to defend themselves against improper punishment. ${ }^{158}$ Such alienation was required, because that was the only way that the state could have the authority to adjudicate and punish violations of the law. For the state to have such authority is for citizens to be required to accept even erroneous punishment. If citizens were bound to accept only correct punishment, they would escape the state's authority simply whenever they were innocent of any wrongdoing. And that would put everyone right back into the state of nature.

By the same token, those entering civil society must alienate their natural rights to defend themselves against harm, if the state is to have the authority to determine when and where self-defense is appropriate. ${ }^{159}$ To say that the government has the authority to regulate self-defense through the criminal law is to say that citizens are bound by its decisions concerning appropriate self-defense even when these decisions are wrong.

Citizens are bound by two types of wrong decisions concerning the scope of self-defense. First of all, they are bound by decisions that fail to recognize what would be correct self-defense in the state of nature. For in the state of nature one may undertake to defend oneself without regard to the riskiness of one's actions. ${ }^{160}$ But the whole point of entering civil society is to allow for the regulation of such risky activities. If one retained one's full natural right to self-defense, the state would have no authority to prohibit unreasonable (even reckless) self-defense that turned out to be justified ex post.

But one is also bound to abide by governmental decisions that fail to determine accurately the proper level of reasonable selfdefense. Even if one's act of self-defense would not create an unreasonable risk of harm, one is bound to accept governmental decisions that say otherwise. If one alienated only one's natural right to defend oneself unreasonably, not only might much of criminal and tort law

\footnotetext{
EMORY L.J. 1139, 1177-78 n.184 (1996); Murley, supra note 148, at 854-55. But this retained right of self-defense, even if it does exist, cannot justify any legal entitlements. For, as I have already noted, see supra footnote 81 , Hobbes is not speaking of a right of self-defense that puts upon the sovereign a duty to respect this right. It is simply the "right" that the condemned man being dragged to the gallows has to struggle against his executioner, a right that says nothing about what the state may or may not do.

158. See supra notes 83-84 and accompanying text.

159. For the clearest expression of this point in the context of a discussion of the Second Amendment, see Heyman, supra note 39, at 243.

160. See supra notes $153-56$ and accompanying text.
} 
become constitutionalized, ${ }^{161}$ one would escape the authority of the state whenever its laws failed to capture the correct standard of reasonableness. Since people tend to read the scope of their rights and the rights of their kin too broadly, this possibility would mean reintroducing the chaos and feuding that it was the purpose of the social contract to avoid. Accordingly, one must alienate even one's right to defend oneself reasonably. It is for this reason that Locke himself insists that rights to self-defense are not retained upon entering civil society. Someone entering civil society "gives up to be regulated by laws made by the society" the power "of doing whatsoever he thought fit for the preservation of himself." 162

This is the essential reason so many people find natural-rights arguments for the Second Amendment incomprehensible. To give individuals a right to bear arms means increasing their ability to act in accordance with their own moral judgment concerning the scope of selfdefense. Arms enable people to enter into precisely the conflict that the authority of the state is supposed to reduce. It is inconsistent to accept the authority of the state to determine when self-defense is appropriate, and at the same time demand a right to something that allows one to resist its decisions. As a result, critics find supporters of the right to bear arms "anarchistic"163 and opposed to "communal strateg[ies] for collective security." ${ }^{164}$ As Professor Garry Wills has put it:

\footnotetext{
161. If this reserved right to reasonable self-defense were recognized in the Bill of Rights, there would be endless constitutional challenges of every criminal law that determines the appropriate limits of self-defense. It is not surprising, therefore, that courts have refused to read a constitutional right of self-defense into the Due Process Clause. Rowe v. DeBruyn, 17 F.3d 1047, 1052 (7th Cir. 1994); White v. Arn, 788 F.2d 338, 347 (6th Cir. 1986); Fields v. Harris, 675 F.2d 219, 220 (8th Cir. 1982). But see Griffin v. Martin, 785 F.2d 1172, 1177 (4th Cir. 1986) (holding that the Constitution proscribes placing the burden of persuasion as to self-defense on the accused); Isaac v. Engle, 646 F.2d 1129, 1140 (6th Cir. 1980) (Merritt, J., dissenting) (asserting that the Constitution prohibits a state from eliminating the justification of self-defense). For the argument that a due process right to self-defense exists, see Nicholas Johnson, Beyond the Second Amendment: An Individual Right to Arms Viewed Through the Ninth Amendment, 24 RUTGERS L.J. 1, 1-16 (1992) (arguing the right to self-defense is incorporated within the Ninth Amendment); Anders Kaye, Dangerous Places: The Right to Self-Defense in Prison and Prison Conditions Jurisprudence, 63 U. CHI. L. REV. 693, 704-09 (1996) (discussing the constitutional right to self-defense within the context of prison inmates); James E. Robertson, "Fight or F . . " and Constitutional Liberty: An Inmate's Right to Self-Defense when Targeted by Aggressors, 29 IND. L. REV. 339, 358-59 (1995) (same).

162. LOCKE, supra note $16, \S 129$; see also id. $\S 171$ (explaining that individuals give up power to the political community to preserve "lives, liberties, and possessions").

163. Bogus, supra note 12, at 320.

164. Bellesiles, supra note 8 , at 259 .
} 
Every civilized society must disarm its citizens against each other.... Every handgun owned in America is an implicit declaration of war on one's neighbor. When the chips are down, its owner says, he will not trust any other arbiter but force personally wielded. ${ }^{165}$

Standard-right justifications of the Second Amendment run into the very same problems as standard-right justifications of the privilege. The rights to self-defense that could justify the constitutional right were alienated to create civil society.

\section{Instrumental-Right Justifications}

Many defenders of the Second Amendment believe that widespread gun ownership increases the level of security enjoyed by individuals. ${ }^{166}$ If they are correct, then the right to bear arms can be justified instrumentally. Because individuals entering civil society alienate their natural rights in part in order to enhance their personal security, they can be understood to limit this alienation by the requirement that they enjoy a certain level of protection from harm (presumably greater than that enjoyed in the state of nature). The enjoyment of this level of security is a reserved right. If widespread gun ownership can help protect this reserved right, it can be justified even though there is no noninstrumental argument for reserving the right to use arms in self-defense, the way that there is a noninstrumental argument for reserving the right to privacy.

Many Second Amendment defenders believe that arms do not merely reduce the threat of violence from fellow citizens, but also the risk that the government will violate their other reserved rights. ${ }^{167}$ Just as defenders of the privilege point to its use during the McCarthy era, Second Amendment advocates look to the postbellum South, where African-Americans' access to arms allowed them not merely to protect their right to personal security against the Ku Klux Klan but also

165. Quoted in Don B. Kates, Jr., Public Opinion: The Effects of Extremist Discourse on the Gun Debate, in The Great American Gun Debate: EsSAYs on Firearms AND Violence 93, 109 (Don B. Kates, Jr. \& Gary Kleck eds. 1997).

166. Barnett \& Kates, supra note 157, at 1234-59; John R. Lott, Jr. \& David B. Mustard, Crime, Deterrence, and Right-To-Carry Concealed Handguns, 26 J. LEG. STUD. 1, 64-65 (1997); Lund, supra note 35, at 123-29.

167. Stephen P. Halbrook, That Every Man Be Armed 72 (1994) (arguing that an armed populace can defend against domestic tyranny). 
their other reserved rights against hostile state authorities. ${ }^{168}$ The Second Amendment is justified instrumentally as "a paramount right by which other rights could be protected."

It is common for those giving such arguments to cite Blackstone. ${ }^{170}$ However, Blackstone himself denied that those entering civil society would reserve any countermajoritarian moral rights. ${ }^{171}$ His reason is the Lockean paradox: If there were such reserved rights, then an individual could escape the authority of the state simply by claiming that these reserved rights were violated. Since Blackstone rejects moral rights to resist the majority, he has no reason to give individuals legal rights to resist the majority. For Blackstone, the right to bear arms is instead a political right - the legal expression of the moral right of the political community as a whole to use arms to resist a tyrannical minority.

But by adopting a more strictly Lockean approach, under which moral rights against the political community are reserved, the argument that the right to bear arms is an instrument for the protection of reserved rights is indeed possible, provided that arms do increase the likelihood that the government will respect reserved rights. If arms perform this function, there would be a reason for the political community to entrust its authority only to governments that have a right to bear arms in their constitutions as a second line of defense for these rights.

Not surprisingly, critics of the Second Amendment reject these instrumental arguments. If arms really made individuals more secure, then there is less reason for them to enter into civil society in the first place. A foundational premise of social contract theory is that individuals' judgments concerning natural rights tend to be distorted by self-interest. People tend to perceive the extent of their rights and the rights of their kin too broadly, leading to feuding and mistaken acts of self-defense. The right to bear arms, by giving individuals the power to act on these flawed perceptions, simply reintroduces the chaos of

\footnotetext{
168. See, e.g., Cottrol \& Diamond, supra note 35 at 348-49 ("[The right to bear arms], seen in the eighteenth century as a mechanism that enabled a majority to check the excesses of a potentially tyrannical national government, would for many blacks in the twentieth century become a means of survival in the face of private violence and state indifference.").

169. United States v. Emerson, 46 F. Supp. 2d 598, 604 (N.D. Tex. 1999).

170. 1 BlACKSTONE, supra note 36, at 139-41; see e.g. MALCOLM, supra note 35 , at 130; Cottrol \& Diamond, supra note 35, at 322-23; Kates, supra note 35, at 93; Lund, supra note 35, at $120 \mathrm{n} .41$.

171. See supra notes $39-45$ and accompanying text.
} 
the state of nature that civil society was supposed to end. ${ }^{172}$ It is "a prescription for anarchy - anarchy that is inconsistent with the protection of the other rights in the Bill of Rights." ${ }^{173}$

Furthermore, critics argue that a right to bear arms cannot protect rights that individuals or small groups have against the political community, for the political community will always have more arms than they do. ${ }^{174}$ Minorities "should fear a regime of decentralized violence because they are relatively weak and powerless; they do not have as many guns as their enemies." 175 Only if the majority of the population were virtuous and therefore inclined to recognize individual rights would a right to bear arms indirectly protect these rights, by allowing the political community to restrain minorities who sought to violate them. ${ }^{176}$

In the end, the debate over instrumental justifications of the Second Amendment comes down to one's views about the ability of private ordering to bring about a stable and just society. But the fact remains that beliefs about the aggregate social effects of the use of guns for self-defense are not the best indicator of support for the right to bear arms. ${ }^{177}$ There are plenty of defenders of the Second Amendment who think that it protects something of moral importance despite the fact that its aggregate social effects are largely negativethat is, even though it increases the general risk of violence and does nothing to increase the chances that the government will respect

172. David C. Williams, Constitutional Tales of Violence: Populists, Outgroups, and the Multicultural Landscape of the Second Amendment, 74 TUL. L. REV. 387, 483 (1999); see also Bellesiles, supra note 8 , at 250 ("Who chooses when it is time for 'the people' to use their arms against the government? Does Linda Thompson get to choose? Timothy McVeigh?").

173. Dennis A. Henigan et Al., Guns And the Constitution: The Myth of Second Amendment Protection for Firearms in America 21 (1996); see also Andrew D. Herz, Gun Crazy: Constitutional False Consciousness and Dereliction of Dialogic Responsibility, 75 B.U. L. REV. 57, 112 (1995) (stating that the Second Amendment ideology has contributed to "America's unparalleled level of gun violence").

174. See Carl T. Bogus, Race, Riots, and Guns, 66 S. CAL. L. REV. 1365, 1367 (1993) (“African-Americans have been particularly victimized by guns and the so-called 'right to bear arms."”).

175. Williams, supra note 172, at 463.

176. Williams, Civic Republicanism, supra note 8, at 63-68, 585-86; Williams, Militia Movement, supra note 8, at 904.

177. Dan M. Kahan, The Secret Ambition of Deterrence, 113 HARV. L. REV. 413, 451 (1999) ("Deterrence considerations don't genuinely explain opinions on either side [of the debate over the Second Amendment and gun control]. Expressive considerations matter much more: for proponents and opponents alike, guns and gun control bear social meanings that go to the heart of their fundamental moral commitments and cultural identities."). 
other reserved rights. ${ }^{178}$ The right to bear arms is not justified instrumentally. Instead the use of arms in defense of one's other rights is itself something to which one has a reserved right.

In this respect, Second Amendment advocates sound just like other civil libertarians. ${ }^{179}$ The argument for the Fourth Amendment is not refuted by the fact that this right increases the incidence of violence and criminality in society. ${ }^{180}$ The point of the Fourth Amendment is that the very thing that it protects-privacy-is of moral value. It simply does not matter, as far as the justification of the Fourth Amendment is concerned, that protecting privacy has social costs. Instead, these social costs merely come into play in determining the scope of this right.

As I have argued earlier, these intuitions stand behind standardright arguments that the right to bear arms protects a reserved right to self-defense. The problem with such arguments, however, is that an essential purpose of entering into the social contract is the alienation of this right.

\section{Auxiliary-Right Justifications}

But to say that one alienates one's natural right to self-defense does not mean that one alienates it unconditionally. Just because someone entering civil society no longer has the right to act as he sees

178. See, e.g., id. (explaining that support for the Second Amendment often stems from the supporter's ideology rather than from a belief in the instrumental effect of broad Second Amendment rights).

179. See L.A. Powe, Jr., Guns, Words, and Constitutional Interpretation, 38 WM. \& MARY L. REV. 1311, 1401 (1997):

The Bill of Rights creates spheres of autonomy from government in which individuals can choose whether to exercise a set of guarantees. The Second Amendment is no less a part of these guarantees than speech, religion, protection from self-incrimination, or the right to be paid if government takes your property. The Second Amendment's pedigree and birth certificate are remarkably similar to the First's ....

Lund, supra note 143, at $31 \mathrm{n} .72$, 68-69 (comparing the Second Amendment to the First Amendment); Van Alstyne, supra note 8, at 1239-41 (same).

180. The Court routinely speaks of the Fourth Amendment as balancing privacy against law enforcement interests. See New Jersey v. T.L.O., 469 U.S. 325, 337-38 (1985) (holding that a student's privacy interest may outweigh the law enforcement interests in searching a school locker); United States v. Leon, 468 U.S. 897, 906-07 (1984) (noting that the decision whether to impose the "exclusionary sanction" in a particular case requires "weighing the costs and benefits of preventing the use ... of inherently trustworthy tangible evidence"). Since there is a balancing involved, it must be the case that law enforcement interests are, at times, sacrificed to privacy. 
"fit for the preservation of himself and the rest of mankind," 181 does not mean he gives up his right to self-defense utterly. No one can consent to be a slave, that is, to be killed or harmed for any reason whatsoever. Because one alienates one's rights only with the intention to "better . . . preserve himself ... (for no rational creature can be supposed to change his condition with an intention to be worse)," political power is limited. ${ }^{182}$

This means that if the government fails to provide me with adequate personal security or violates my other reserved rights, I return to the state of nature and may once again exercise my natural right to defend myself through arms, even though it might be true that the use of arms, in the aggregate, decreases everyone's security. This idea is very intuitive: if the government abandons me to death at the hands of third parties, it no longer has the authority to require me to abide by its laws. If it did, its authority over me would be absolute. I would be a slave.

The Lockean state must accept the validity of these arguments. The use of arms in self-defense under such circumstances is a form of legitimate defense of one's reserved rights. It is something valuable on its own, as an expression of the Lockean principles of autonomy and individualism. To retain its authority to prohibit the use of arms in self-defense, therefore, the government must claim that it is protecting reserved rights, including the right to sufficient security, even if it fails to protect individuals from harm under all circumstances.

But what happens when the government and an individual disagree about whether this condition for authority has been satisfied? Just as one focal point for disagreement over the state's authority is the criminal trial, another is when an individual is threatened by imminent violence, is unable to use the police or any other arm of the government to protect herself, and yet is prohibited by the state from engaging in what she believes is appropriate self-defense. The government will claim that the individual is still obligated to abide by the laws governing self-defense, even if these laws are wrong, because she is enjoying a level of security greater than what she would enjoy in the state of nature. On the other hand, the individual has a good claim that she has in fact been abandoned by the state and so is free to defend herself as she sees fit.

181. LOCKE, supra note $16, \S 129$.

182. Id. § 131 . 
One now confronts the Lockean paradox. If the government claims the authority to decide these disagreements and prohibit selfdefense no matter what the individual thinks, then its authority is absolute, and citizens are really slaves. Although the government may give everyone plenty of rights to defend themselves, it could abandon them to death at the hands of third parties if it wanted to. Since this conclusion is intolerable, it appears that an auxiliary right to bear arms is necessary. The government must give individuals the rights to engage in self-defense that they would have if it were violating their reserved rights, even though these rights are anarchistic in the sense that they undermine the government's ability to regulate self-defense in situations where it in fact has the authority to do so.

Locke makes the argument for an auxiliary right to bear arms even stronger, by suggesting that when a citizen is threatened with imminent violence, the state in fact has no authority to forbid her from exercising her natural right of self-defense. ${ }^{183}$ The state cannot even begin to offer her a superior alternative to the state of nature under those circumstances where it is unable to enforce its will. These situations are pockets of the state of nature within civil society.

If Locke really means this, then it should follow that the state has no authority to regulate by law one's attempts at self-defense under such circumstances. Assume that I meet someone in the middle of the wilderness. She looks at me in a suspicious way, and her hand moves slightly toward her waist. I respond by obliterating her with a bazooka. My action looks unreasonable (both in terms of the weapon I used and in terms of the method I used to determine whether selfdefense was appropriate). This is true even if the person I killed was

183. See id. § 19:

Thus a thief, whom I cannot harm, but by appeal to the law, for having stolen all that I am worth, I may kill when he sets on me to rob me but of my horse or coat, because the law, which was made for my preservation, where it cannot interpose to secure my life from present force, which if lost is capable of no reparation, permits me my own defence and the right of war, a liberty to kill the aggressor, because the aggressor allows not time to appeal to our common judge, nor the decision of the law, for remedy in a case where the mischief may be irreparable. Want of a common judge with authority puts all men in a state of nature; force without right upon a man's person makes a state of war, both where is, and is not, a common judge.

See also Heyman, supra note 39, at 245 ("Locke holds that when an individual faces an imminent attack on his life or person, he has a right to use all necessary force to defend himself. To this extent, the right to self-defense is an inalienable one which is retained within civil society.") (footnote omitted). 
armed. But the state cannot punish me on these grounds, since it lacks the authority to do so. ${ }^{184}$

The best the government could do is to punish me if self-defense was not justified ex post. In fact it is not even clear that it could do that. The government could punish me on such grounds only if it could rely, not on its authority, but on its perception that I violated natural law. It would simply be acting like any other player in the state of nature, enforcing natural law as it sees fit. The problem with such an approach, however, is that Locke requires that the government's monopoly on force be justified by its authority, not by the fact that it has the naked power to compel everyone else to abide by its perceptions of natural law. ${ }^{185}$ Accordingly, under Lockean principles, it would appear that the government would not be able to regulate my actions in any way in these state-of-nature pockets.

To keep governmental authority from breaking down completely in these situations, one must assume that the government claims the authority to regulate by law even responses to imminent violence. This is not an absurd view. After all, to the extent that the government is protecting citizens from violence, they are benefiting from this at every moment, even when it cannot protect them against a particular threat. But the idea that the government has lost its authority in such cases, despite the anarchistic consequences that follow from such a claim, is not absurd either. And once again, if the government is the one with the authority to decide this disagreement, it must be claiming absolute authority.

This idea that acts of imminent violence put everyone in the state of nature, allowing them to exercise their natural rights of selfdefense, stands behind many natural rights arguments for the Second Amendment. Consider the following passage from National Rifle Association President Charlton Heston's address to the Congress of Racial Equality at its annual banquet in honor of Dr. Martin Luther King, Jr.:

What civil right could possibly be more fundamental than the right to protect your life, your family and your freedom from whoever would take it away?... "All men were created equal" may have

184. Professor Steven Heyman argues that it is Locke's view that the state would retain the authority to regulate the use of arms in situations where one is threatened by imminent violence. Heyman, supra note 39, at 245-46. But he does not say how Locke would justify such authority.

185. See supra note 21-22 and accompanying text. 
been our message in 1963. Today, let our message be just as simple and just as strong: "All people have an unalienable right to defend their lives and their liberty from whomever would harm them, and with whatever means necessary.",186

At first glance, this sounds like an anarchistic denial that anyone entered into the social contract at all. After all, the point of the social contract is to give up natural rights to defend oneself, because the unbridled exercise of these rights leads to feuding. Without such alienation of rights to self-defense, the government would lack any authority to regulate self-defense by law.

And yet Heston's comments are in keeping with Lockean theory after all, for citizens $d o$ have a reserved natural right to defend themselves, including by force of arms. They may exercise this right when the government fails in its duty to provide them with sufficient security or violates other reserved rights. This right to self-defense through force of arms exists even if arms fail to increase the level of security in society or the likelihood that other natural rights will be respected. It instead has its source in Lockean principles of autonomy and individualism. And thus Heston is correct when he says that this is a right to protect oneself "by whatever means necessary" - that is, whatever the level of danger these arms create.

Finally, Heston is also right in implying that an auxiliary legal right to bear arms is necessary to protect this reserved right. For if the government may refuse to provide citizens with the arms they need to protect themselves, it is claiming the authority to determine for itself whether it is providing them with adequate security and is respecting their other reserved rights. And that means its authority is absolute.

Accordingly, just as defenders of the privilege believe that compelled self-incrimination is a form of "debasement" "187 and "subordination of the self to the state," ${ }^{, 188}$ Second Amendment advocates argue that disarming the population is "a humiliating and debasing degradation." 189 Without the right to defend themselves as they see fit, the state can abandon citizens to death if it wants to. They are its slaves.

186. Charlton Heston, Address to the Congress of Racial Equality at Its Annual Banquet in Honor of Dr. Martin Luther King, Jr., at http://www.newsmax.com/archives/articles/2001/3/19/ 210522.shtml (March 2001) (on file with the Duke Law Journal).

187. United States v. Wade, 388 U.S. 218, 261 (1967) (Fortas, J., concurring in part and dissenting in part).

188. LUBAN, supra note 68, at 194.

189. James B. Whisker, The Citizen-Soldier Under Federal and State Law, 94 W. VA. L. ReV. 947, 963 n.52 (1992) (quoting 3 ELLiot's DebAtes 168-69 (statement of Patrick Henry)); 
Understanding the right to bear arms as auxiliary helps explain the close relationship that Second Amendment advocates see between disarming a population and totalitarianism:

If one believes that the people are to serve the state, that the rights of the people are created or granted by the state, or that the security of the state itself has paramount importance, then the right to keep and bear arms is a dangerous vehicle for subversion that must be eliminated; and eliminated it has routinely been in totalitarian countries. $^{190}$

Second Amendment critics are mystified by such views, given that many liberal democracies have extremely restrictive gun control laws. Since these countries give their citizens exactly the same standard rights to free speech, privacy, autonomy and personal security that citizens of the United States receive, it seems absurd to say that they are totalitarian. And yet by failing to give individuals the ability to defend their reserved rights as they see fit, these governments are totalitarian in insisting that the only views about the limits of their authority that matter are their own. They are the authority on the extent of their authority. And that means that their authority has no real limits at all.

Of course, by giving individuals arms to defend their reserved rights, an auxiliary Second Amendment also allows them to use these same arms to frustrate the government's legitimate attempts to assert its authority. Those whose reserved rights are not violated may nevertheless use their arms to frustrate the government's efforts to increase the security of the population. The right to bear arms is anarchistic. These anarchistic consequences in the end frustrate all attempts to delineate the scope of the right in a coherent fashion.

\section{E. The Second Amendment's Incoherent Scope}

Unlike the privilege, the problem of the Second Amendment's scope has not been considered pressing, because the predominant approach of the courts, largely on the authority of the Supreme Court

see also Harmer, supra note 14, at 100 (stating that gun ownership fosters "vigorous virtues of independence, self-reliance and vigilance"); Kates, Handgun Prohibition, supra note 148, at 217 n.53 (arguing that the Founders viewed an armed citizenry as more likely to be independent and self-reliant); Scott Bursor, Note, Toward A Functional Framework for Interpreting the Second Amendment, 74 TEX. L. REV. 1125, 1137-39 (1996) (arguing that the Founders saw possession of arms as essential to citizens' moral development).

190. Harmer, supra note 14, at 55-56. 
case of United States v. Miller, ${ }^{191}$ has been to read the Second Amendment as ensuring only that formal and organized state militias may remain armed. ${ }^{192}$ These interpretations have guaranteed that virtually no Second Amendment challenge of gun control legislation would succeed.

But recently, in United States v. Emerson, ${ }^{193}$ the Fifth Circuit Court of Appeals concluded that Miller does not take a stand one way or the other concerning a states-rights interpretation of the Second Amendment. ${ }^{194}$ Since Miller left the issue open, the Emerson court was free to accept revisionist arguments that the text and legislative history of the Second Amendment shows that it was intended to "protect[] the right of individuals ... to privately possess and bear their own firearms." 195

Emerson put the scope of the Second Amendment on center stage. But because it did not answer the question of what moral role the Second Amendment plays, the Emerson Court was unable to give a reason why it limited the scope of the Second Amendment as it did. ${ }^{196}$ Although the court rejected what it called "collective right" interpretations, it meant by this only views that the Amendment protects the rights of states. ${ }^{197}$ The court did not specifically endorse the view that the Second Amendment protects reserved rights of individuals against the political community. To be sure, it quoted approvingly passages that supported such a view. ${ }^{198}$ But it quoted just as

191. 307 U.S. 174 (1939).

192. Hickman v. Block, 81 F.3d 98, 100-01 (9th Cir. 1996); Love v. Pepersack, 47 F.3d 120, 124 (4th Cir. 1995); United States v. Warin, 530 F.2d 103, 106 (6th Cir. 1976); Stevens v. United States, 440 F.2d 144, 149 (6th Cir. 1971).

193. 270 F.3d 203 (5th Cir. 2001).

194. Id. at 221-27.

195. Id. at 260 .

196. The particular question of scope was whether Emerson's Second Amendment rights prevented his indictment for possessing a firearm while subject to a temporary injunction, brought against him by his wife in the context of divorce proceedings, that prohibited "the use, attempted use, or threatened use of physical force against ... [an] intimate partner or child." Id. at 212-15 (referencing 18 U.S.C. $\$ 922(\mathrm{~g})(8)(\mathrm{C})(\mathrm{ii})$ (2000)). The Emerson court concluded that it did not. Emerson, 270 F.3d at 260-64. Despite the fact that the court issuing the injunction did not arrive at an explicit finding that Emerson posed a credible threat of violence to his wife and children, the Emerson court found that the general evidentiary standards for a temporary injunction under Texas law established a sufficient nexus with "lawless violence" to override Emerson's right to bear arms. Id. at 264. But it did not explain why Emerson's Second Amendment right should be overridden in this fashion. It simply took for granted that a nexus with lawless violence was sufficient to do so.

197. Emerson, 270 F.3d at 221-27.

198. Id. at $255-57$. 
approvingly passages in which the Second Amendment was interpreted as a political right to participate in a communitarian revolution against a tyrannical minority. ${ }^{199}$

One must look instead to the academic literature on the Second Amendment to get some idea of what a principled delineation of its scope would look like..$^{200}$ I have already suggested the probable scope of a political right to bear arms, which would be too narrow to satisfy most Second Amendment advocates, since it would protect only the right to bear arms in the event of a communitarian political rebellion. ${ }^{201}$

More significant for my purposes are the academic attempts to determine the scope of an individual right to bear arms. Don B. Kates, Jr., for example, has argued that such a right would exclude "weapons such as machine-type guns, flamethrowers, artillery, and atomic weapons, whose use, even in strict self-defense, would quite obviously menace one's neighbors." 202 In the same spirit, Stephen P. Halbrook has suggested that its scope should exclude "dangerous and unusual" weapons, such as bombs or grenades, because of their tendency to harm both the innocent and the guilty. ${ }^{203}$

Although this limitation might make sense if the right to bear arms is instrumental, it seems curiously divorced from the "natural right" of self-defense that, they claim, the Second Amendment is supposed to protect. ${ }^{204}$ Such a natural right, it will be remembered, has

199. E.g., id. at 252 (quoting Federalist Tench Coxe's 1789 article, which suggests that "the people are confirmed ... in their right to keep and bear their private arms" to defend the country against tyrannical "civil rulers." Tench Coxe (originally published under the pseudonym "A Pennsylvanian"), Remarks on the First Part of the Amendments to the Federal Constitution, Phila. Fed. GAZETTE, June 18, 1789, at 2, col 1).

200. Virtually every academic supporter of an individual-right approach has recognized that, like any other constitutional right, the Second Amendment must be limited in scope in accordance with its social costs. See, e.g., Col. Charles J. Dunlap. Jr., Revolt of the Masses: Armed Civilians and the Insurrectionary Theory of the Second Amendment, 62 TENN. L. REV. 643, 677 (1995) ("[The Second Amendment] should be subject to the same balancing test that has been successfully used in reconciling conflicting interests with respect to other amendments."); Lund, supra note 143, at 49 (suggesting that the Second Amendment requires "balancing individual liberty against public safety").

201. Jack N. Rakove, The Second Amendment: The Highest Stage of Originalism, 76 CHI.KENT L. REV. 103, 159-60 (2000).

202. Don B. Kates, Jr., The Second Amendment: A Dialogue, 49 LAW \& Contemp. Probs. 143, 146 (Winter 1986).

203. Stephen P. Halbrook, What the Framers Intended: A Linguistic Analysis of the Right to "Bear Arms", 49 LAW \& CONTEMP. PROBS. 151, 160 (Winter 1986).

204. HALBRoOK, supra note 167 , at 17; Barnett \& Kates, supra note 157, at 1177; Kates, Handgun Prohibition, supra note 148, at 230; Kates, supra note 35, at 89-103; Glenn Harlan 
value independently of its tendency to increase or decrease the security of the population. The natural right applies whenever in a particular situation arms are necessary to protect one's reserved rights. As Nelson Lund, criticizing Halbrook's analysis, has noted:

This argument seems to assume that no citizen would ever be attacked by someone who was protected by armor. The argument also seems to assume that aggressors are always surrounded by innocent people who would be endangered by the use of devices like grenades or bazookas. Both assumptions would likely prove false in the very circumstances that most immediately concerned the Framers of the Second Amendment: attempts at political oppression by the government. ${ }^{205}$

The same point can be made about who may legitimately be prohibited from carrying arms. For example, in response to the question of whether convicted felons have Second Amendment rights, the Emerson court said, without explanation, that "it is clear" they do not. ${ }^{206}$ But the conclusion that felons lose their right to bear arms assumes that someone legitimately struggling against the government would never have been convicted of a felony. And this, of course, is false. Indeed, felons would appear to be the type of people who should particularly have a right to bear arms, since someone involved in a campaign of legitimate civil disobedience is likely to have been convicted of a felony at some point.

I believe that Lund criticizes Halbrook's attempt to limit the right to bear arms because Halbrook fails to take seriously the idea that the Second Amendment protects a natural right to self-defense. It is for this reason that Lund concentrates on just those cases where this natural right may be invoked-when the government, by violating citizens' reserved rights, loses its authority to regulate their actions in the interest of the common good.

But if the right to bear arms is to do justice to this natural right of self-defense, then it is hard to see how one can avoid its taking on anarchistic dimensions. The government cannot say to the Catholic forbidden by law to practice his religion that she may resist the tanks that enforce these laws with a rifle, but not with a bazooka, because the social costs of bazookas are too great. The government lost its

Reynolds \& Don B. Kates, The Second Amendment and States' Rights: A Thought Experiment, 36 WM. \& MARY L. REV. 1737, 1738 (1995).

205. Lund, supra note 143 , at $45-46$.

206. United States v. Emerson, 270 F.3d 203, 261 (5th Cir. 2001). 
authority to prohibit her from carrying a bazooka when it violated her reserved right against religious discrimination. Nor can the government say to blacks it abandons to the Ku Klux Klan that they can use a pistol, but not a machine gun, to defend themselves against a lynch mob, because machine guns, if misused, are too dangerous. For the government lost the authority to forbid their use of machine guns when it violated their rights to personal security.

To be sure, as the social costs of protecting the natural right of self-defense grow, one will find the desire to limit the scope of the Second Amendment overwhelming. A line will be drawn. But where it is drawn will conceptually and morally unmotivated. It will be precisely the same type of ad hoc balancing that has become the norm in Fifth Amendment jurisprudence. ${ }^{207}$

\section{CONCLUSION}

This, then, is the paradox of auxiliary rights, as it expresses itself in the Constitution. I do not want to suggest that the paradox is unavoidable. It can be sidestepped, by rejecting one of the Lockean principles upon which it is based. For example, one can argue, with Blackstone, that the authority of the political community is unlimited. ${ }^{208}$ Or one can argue that the political community may exercise a monopoly on force without any authority-it is simply enough that it has the power to compel everyone else to comply by its views. ${ }^{209}$ But

207. I cannot examine at this point what the scope of an instrumental right to bear arms would look like, although it should be noted that, as with other instrumental rights, its scope in uncertain cases should be viewed in the light of the moral right that it indirectly protects, namely, the right to security.

208. See 1 Blackstone, supra note 36 , at $* 156$ ("[Parliament] hath sovereign and uncontrolable authority in making, confirming, enlarging, restraining, abrogating, repealing, reviving, and expounding [all] laws ... this being the place where that absolute despotic power, which must in all governments reside somewhere, is entrusted by the constitution of these kingdoms.").

209. This is the approach that I took in Green, supra note 22, and which I attributed to Locke there. When the government and an individual disagree about whether the government is acting within its authority, the government may forbid civil disobedience, despite the fact that it has no authority to decide this disagreement, because it is simply exercising the prerogative of any agent in the state of nature to act on his perceptions of natural law. For this reason, I saw no reason why the government would have a duty to give individuals powers to defend themselves when such disagreements occur. As a result, auxiliary rights did not follow from Lockean principles. The only purpose that a Lockean could find for the privilege, I argued, was the much less plausible one of giving symbolic expression to the fact that the government has no authority over the defendant and that the two are simply in the state of nature.

It is still my view that the government does not need authority to exercise a monopoly of force. For this reason, I personally am opposed to the privilege against self-incrimination and 
these positions are not Locke's and, for this reason, conflict with the political theory held by the Founders and standing at the heart of the Bill of Rights.

To the extent that one remains attached to Lockean political theory, therefore, one must accept that auxiliary rights are paradoxical and that each side in the debate over these rights is worthy of both criticism and respect. Furthermore, as long as these rights are retained in the Constitution, one must lower one's expectations concerning the coherence of judicial determinations of their scope.

the right to bear arms, understood as auxiliary rights. But I no longer believe that this follows from Lockean principles. 